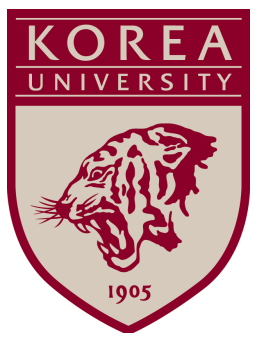

Discussion Paper Series

No. 1606

October 2016

\title{
Are Exchange Rates Disconnected from Macroeconomic Variables? \\ Evidence from the Factor Approach
}

Yunjung Kim, Cheolbeom Park

The Institute of Economic Research - Korea University

Anam-dong, Sungbuk-ku, Seoul, 136-701, South Korea, Tel: (82-2) 3290-1632, Fax: (82-2) 928-4948

Copyright (C) 2016 IER. 


\title{
Are Exchange Rates Disconnected from Macroeconomic Variables?
}

\section{Evidence from the Factor Approach*}

\author{
Yunjung Kim \\ Korea University \\ and \\ Cheolbeom Park \\ Korea University
}

September 2016

\begin{abstract}
We use factor-augmented predictive regression to analyze the relation between nominal exchange rates and macroeconomic variables. Using a panel of 127 US macroeconomic time series, we estimate eight factors through principal component analysis. Those estimated factors have significant predictive power and can substantially improve the predictive power of Purchasing Power Parity through both in-sample and out-of-sample analyses. The estimated macroeconomic factor, which comoves with US money supply measures, has strong predictive power for nominal exchange rate fluctuations in the short run, while estimated factors, comoving with interest rate spreads and employment variables, have strong predictive power in the long run. Moreover, optimal factors selected by the BIC in the out-of-sample analysis differ greatly depending on the time points when forecasts are made. Finally, we show that factors extracted from a panel of 127 US time series data and those extracted from a panel of 215 Korean macroeconomic series together can predict a substantial portion of movements in the Korea-US bilateral exchange rate.
\end{abstract}

Keywords: exchange rate, macroeconomic variables, factor approach, predictive regression

JEL Classification: F31, F37, F47

\footnotetext{
*Yunjung Kim: Department of Economics, Korea University, Anamro 145, Seongbuk-gu, Seoul, Korea 02841; kimyjh@naver.com.

Cheolbeom Park (Corresponding Author): Department of Economics, Korea University, Anamro 145, Seongbuk-gu, Seoul, Korea 02841; +82-2-3290-2203; Fax: +82-2-3290-2200; cbpark_kjs@korea.ac.kr.
} 


\section{Introduction}

Since Meese and Rogoff (1983) questioned the ability of macroeconomic variables to forecast exchange rates, many economists have investigated this issue. Although numerous macroeconomic models have been proposed and examined empirically, the empirical findings on the relation between exchange rates and macroeconomic variables differ greatly depending on the selected macroeconomic variables, sample periods, countries, length of forecast horizons, econometric methodologies, and other factors. For example, while Mark (1995) and Chinn and Meese (1995) report that variables based on the monetary model with flexible prices have significant predictive power for future exchange rate changes, Kilian (1999) and Berkowitz and Giorgianni (2001) show that those results are not robust for extended sample periods. Later, however, Park and Park (2013) argue that those variables have strong ability to predict future exchange rate movements through the time-varying cointegration approach.

We address the literature's inconsistent and controversial results on the forecasting ability of macroeconomic variables by employing the factor-augmented predictive regression framework. Specifically, we use a panel of 127 monthly macroeconomic variables in the US to determine the relation between exchange rates and macroeconomic variables. The factor approach, developed by Stock and Watson (2002) and Bai and Ng (2002, 2006), enables us to extract latent factors from the underlying panel of variables and test whether those latent factors have significant predictive power for future exchange rate movements. This factor approach can be particularly effective in examining the relation between exchange rates and macroeconomic data in several ways. First, previous studies have used a few selected macroeconomic variables and reported controversial results, but the factor approach enables us to avoid arbitrary decisions on the selection of macroeconomic variables. Instead, we can 
utilize information contained among the large number of macroeconomic data without causing a dimension problem due to a large number of predictors. Second, factors estimated from a large number of macroeconomic data are less noisy and have better explanatory power than individual time series data (see Stock and Watson (2002) and Moench (2008)).

Using the advantages of the factor approach, we apply the factor-augmented predictive regression framework to 26 economies' bilateral US dollar exchange rates. ${ }^{1}$ We find that estimated factors from a panel of US macroeconomic data have significant predictive power for future nominal exchange rate changes, even without accounting for nonUS counterpart economies. The predictive power of those factors is particularly pronounced when the estimated factors are combined with the real exchange rate in both in-sample and out-of-sample analyses. Moreover, we show that individual factors' predictive powers differ over forecasting horizons, implying that different macroeconomic information is needed to forecast nominal exchange rate changes over different forecast horizons. After identifying the US macroeconomic variables comoving with those estimated factors, we find that the factor comoving with money supply variables in the US has greater predictive power for nominal exchange rate changes over short horizons, whereas the factors covarying with employment variables, interest rate spreads, and stock market variables in the US are selected more frequently as significant factors over long horizons. Moreover, the optimal factors selected by the BIC in the out-of-sample analysis differ greatly depending on the time points when forecasts are made. These findings echo Cheung and Chinn (2001), who report that the list of important macroeconomic variables and models in currency traders' mind to understand movements in exchange rates shifts over time. Moreover, the findings can explain why

\footnotetext{
${ }^{1}$ Exchange rates are defined as the amount of local currency needed to purchase one US dollar.
} 
previous studies provide conflicting results, even when a large panel of macroeconomic variables is stably related with exchange rate fluctuations. Finally, we add estimated factors from a panel of Korean time series variables as well as estimated US factors in the predictive regression and show that factors from Korea and US together predict a substantial portion of movements in the Korea-US bilateral exchange rate, confirming the connection between macroeconomic variables and exchange rates.

Our study is similar to Ludvigson and $\mathrm{Ng}(2009,2010)$ and Jurado, Ludvigson, and $\mathrm{Ng}$ (2015) in the sense that latent factors are extracted from a large number of macroeconomic variables, but it is also different in the sense that those factors are used to forecast bilateral US dollar exchange rate changes instead of bond returns, or to measure uncertainty. Similarly to Engel, Mark, and West (2014) and Greenaway-McGrevy et al. (2015), we apply the factor approach in predicting exchange rates. Unlike those studies, however, we estimate factors from a panel of US macroeconomic data and/or a panel of Korean macroeconomic series instead of a panel of exchange rate data.

The rest of this paper is organized as follows: Section II presents our econometric methodology. Data sources and estimated factors from a large set of macroeconomic series are presented in Section III. The results of an in-sample analysis are shown in Section IV. Section V provides evidence from an out-of-sample analysis. Section VI presents the results of the predictive regression with factors estimated from a panel of Korean time series as well as estimated US factors. Finally, concluding remarks are offered in Section VII.

\section{Econometric Methodology}


Although the exchange rate is a macroeconomic variable monitored by policymakers and economists, its movements are not well explained by other macroeconomic variables, and its impact on other macroeconomic variables also seems limited. This phenomenon has been reported by many studies since Meese and Rogoff (1983) and is named the "exchange-rate disconnect puzzle” by Obstfeld and Rogoff (2001). In this literature, a standard approach to assessing whether nominal exchange rate changes are predictable by macroeconomic variables uses the following predictive regression:

$$
\Delta s_{i, t+h}=\beta_{0, i}+\beta_{i, h}^{\prime} X_{t}+\varepsilon_{i, t+h}
$$

where $s_{i, t}$ denotes the log of the nominal exchange rate between the currency of country $i$ and US dollars, and $X_{t}$ denotes a vector of macroeconomic predictors.

$X_{t}$ in Equation (1) usually consists of a few macroeconomic variables, depending on the underlying model. However, this approach could be restrictive because the forecast ability of a macroeconomic series depends on the selected macroeconomic variables, sample periods, forecast horizons, and other decisions. Furthermore, Cheung and Chinn (2001) find from a survey of US foreign exchange traders that the importance foreign exchange traders attach to macroeconomic fundamentals varies over time. Observing the unstable relation between exchange rates and a few selected macroeconomic series, we seek to address whether macroeconomic series have significant predictive power for future exchange rate changes utilizing a large number of macroeconomic variables together. However, when the number of macroeconomic series (denoted by $N$ ) is greater than the number of time periods (denoted by $T$ ), this approach with a large number of variables is not feasible. To overcome this problem, we assume the following factor structure for US macroeconomic variables: 


$$
x_{j, t}=\lambda_{j}^{\prime} F_{t}+e_{j, t}
$$

where $x_{j, t}$ is an individual series contained in $X_{t}, F_{t}$ is a $r \times 1$ vector of common factors, $\lambda_{j}$ is a corresponding $r \times 1$ vector of factor loadings, and $e_{j, t}$ is an idiosyncratic error. $e_{j, t}$ can be serially correlated and weakly correlated across series, as in Stock and Watson (2002).

We estimate $F_{t}$ using the principal component analysis (PCA). Bai and $\mathrm{Ng}$ (2002) and Stock and Watson (2002) show that the space spanned by $F_{t}$ can be consistently estimated by $\hat{F}_{t}$ (an estimate of $F_{t}$ by PCA) as both $N$ and $T \rightarrow \infty$. We employ the information criterion $\left(\mathrm{IC}_{2}\right)$ developed in Bai and $\mathrm{Ng}$ (2002) to determine the number of factors. When we apply $I C_{2}$ to the panel of 127 macroeconomic series, we find eight factors over the full sample. ${ }^{2}$ Having obtained these factors, we run the following predictive regressions for 26 economies to check if the estimated factors from US macroeconomic data are helpful in forecasting nominal exchange rates:

$$
\Delta s_{i, t+h}=\alpha_{0, i}+\alpha_{F, i, h}^{\prime} \hat{f}_{t}+\alpha_{Z, i, h}^{\prime} Z_{t}+\varepsilon_{i, t+h}
$$

where $\hat{f}_{t}$ denotes an estimate of a subset of $F_{t}$, and $Z_{t}$ is a vector of the observable predictor. We run regression equation (3) both without $Z_{t}$ and with $Z_{t}$ in the empirical analysis. When we include $Z_{t}$, we use the real exchange rate to represent Purchasing Power Parity (PPP) fundamentals, which are reported to have the strongest predictive power among macroeconomic models in Engel, Mark, and West (2008). Moreover, PPP fundamentals are also expected to reflect the relative macroeconomic conditions between US and non-US economies. Since the factors that are pervasive in the panel of US macroeconomic series are

\footnotetext{
2 Since exchange rates are removed from the set of macroeconomic series, the panel of 127 macro series does not contain exchange rate data.
} 
not necessarily important for forecasting $\Delta s_{i, t+h}, f_{t} \subset F_{t}$. Since Bai and Ng (2006) show that the least squares (LS) estimate of $\alpha_{F, i, h}^{\prime}$ is consistent and asymptotically normal as $N, T \rightarrow \infty$ and $\sqrt{T} / N \rightarrow 0$, we apply the LS estimation to Equation (3) to examine the predictive power of factors from the US macroeconomic variables on a panel of bilateral US dollar rates.

\section{Data and Latent Factors from US Macroeconomic Series}

\section{A. Data}

Nominal exchange rate data for 26 countries are obtained from International Financial Statistics (IFS). ${ }^{3}$ Nine currencies that switched to the euro at the beginning of 1999 are rescaled using bilateral euro rates to avoid discontinuity for those currencies. The consumer price indices (CPI) of the associated countries are also taken from IFS. After removing bilateral US dollar rates, 127 macroeconomic series are obtained from Ludvigson’s website. ${ }^{4}$ This dataset is basically that used in Jurado, Ludvigson, and Ng (2015) and contains information about various aspects of the US economy, such as real output, income, employment, consumer spending, housing market condition, inventories, money stock, interest rates and spreads, stock market indicators, and price indices. All of the macroeconomic data are standardized prior to estimation, as in Ludvigson and $\mathrm{Ng}$ (2009). The sample period covers January 1973 to December 2011, as dictated by the availability of

\footnotetext{
${ }^{3}$ The 26 countries examined in this study are Australia, Austria, Belgium, Canada, Chile, Colombia, Denmark, Finland, France, Germany, Iceland, Italy, Japan, Korea, Netherlands, New Zealand, Norway, the Philippines, Portugal, Singapore, South Africa, Spain, Sweden, Switzerland, Thailand, and the United Kingdom.

${ }^{4}$ Ludvisgon’s homepage can be found at http://www.sydneyludvigson.com/.
} 
the panel of macroeconomic variables.

\section{B. Latent Factors from US Macroeconomic Series}

We apply PCA to 127 macroeconomic series to estimate the latent factors, the number of which is determined by $I C_{2}$. This criterion selects eight factors from the series under investigation, consistent with the results in Ludvigson and Ng (2009) and Jurado, Ludvigson and Ng (2015). Autocorrelation coefficients and cumulative $R^{2} \mathrm{~s}$ for these eight factors are reported in Table 1 . The factors exhibit some, but not extreme, persistence. $\widehat{F}_{1 t}$ exhibits the highest autocorrelation (0.81) among the eight factors. $\hat{F}_{1 t}$ also explains $19 \%$, the largest fraction, of the total variation in the macroeconomic dataset. The eight factors together can explain more than $54 \%$ of the total variation in the 127 macroeconomic series.

Factor analysis is often criticized for making it difficult to give an economic meaning to the estimated factors. To mitigate this problem, we regress each of the 127 US macroeconomic series on each of those eight factors and obtain $R^{2} \mathrm{~s}$. Based on the obtained $R^{2} \mathrm{~s}$, we identify which macroeconomic variables are closely related with those factors. Figures 1 and 2 plot each of the eight factors together with those closely related macroeconomic series. As shown in the top panel of Figure $1, \hat{F}_{1 t}$ moves closely with various measures indicating US employment conditions, while $\hat{F}_{2 t}$ varies tightly with interest rate spreads (both credit spreads and long-run term spreads). $\hat{F}_{3 t}$ and $\hat{F}_{4 t}$ are related with prices and interest rates, respectively. $\hat{F}_{5 t}$ shares components with short-term interest rate term spreads. Although it is difficult to relate one economic sector to $\hat{F}_{6 t}, \hat{F}_{6 t}$ seems to covary with stock market variables and investment variables. $\hat{F}_{7 t}$ comoves with stock 
market variables and industrial production variables, and $\hat{F}_{8 t}$ is strongly correlated with measures of money supply.

\section{Predictive Regression: In-sample Analysis}

\section{A. Optimal Factors vs. PPP}

Utilizing the estimated factors from the panel of US macroeconomic series, we first run a predictive regression (3) without including any observable predictor (i.e., without $Z_{t}$ ). For each country and for each horizon (one month, three months, six months, 12 months, and 24 months), we select the subset of eight factors that minimizes the BIC criterion and regress nominal exchange rate changes on those selected factors. Note that the factors that are important for the total variation of a macroeconomic series do not necessarily have the best ability to forecast $\Delta s_{i, t+h}$. Hence, the factors selected by the BIC criterion do not need to be $\widehat{F}_{1 t}$ or $\widehat{F}_{2 t}$. Figure 3 shows the frequencies at which each factor has been selected for each horizon. $\hat{F}_{8 t}$, which is closely related with US money supply measures, is selected at overwhelming frequencies for the one-month horizon, but other factors are selected more frequently as the horizon increases. This pattern suggests that factors with strong predictive power for nominal exchange rate movements differ across horizons. $\hat{F}_{8 t}$, which covaries with US money supply measures, plays an important role in predicting exchange rates in the short run. For longer horizons such as one year and two years, however, $\widehat{F}_{1 t}, \widehat{F}_{4 t}$ and $\widehat{F}_{5 t}$, which are related to US real economic activity such as employment conditions and interest rate spreads, become important in explaining exchange rate changes. In contrast with $\widehat{F}_{1 t}, \widehat{F}_{4 t}$, $\widehat{F}_{5 t}$ and $\hat{F}_{8 t}, \hat{F}_{3 t}$, related to the price sector, is rarely selected as an optimal factor in the 
predictive regression. Table 2 shows adjusted $R^{2}$ from $\Delta s_{i, t+h}=\alpha_{0, i}+\alpha_{F, i, h}^{\prime} \hat{f}_{t}+\varepsilon_{i, t+h}$. Although the predictive power of the factors estimated from the US macroeconomic series to explain bilateral exchange rate movements differ greatly across counterpart countries, the predictive power as measured by adjusted $R^{2}$ generally increases with the forecast horizon. The magnitude of the predictive power is substantial: the average adjusted $R^{2}$ ranges from $1.3 \%$ at a one-month horizon to $21 \%$ at a two-year horizon.

To compare the predictive power of the optimal factors chosen by the BIC with that of PPP, the following predictive regression, with only the real exchange rate, is run:

$$
\Delta s_{i, t+h}=\gamma_{0, i}+\gamma_{0, i, h} q_{i, t}+\varepsilon_{i, t+h}
$$

where $q_{i, t}$ is the real exchange rate between country $i$ and US. Comparing Table 2 with the PPP columns in Table 3, we note that the optimal factors selected by the BIC show much better forecasting ability than PPP shows at a one-month horizon in terms of adjusted $R^{2}$. For a one-month horizon, adjusted $R^{2}$ s improve in 21 out of 26 countries when the optimal factors from the US macroeconomic series (instead of the real exchange rate) are used in the predictive regression. This result is notable because we use factors from the US macroeconomic variables only, without considering any of the variables from counterpart countries. Possibly due to this limit, however, PPP shows better performance in predicting nominal exchange rate changes at three- and six-month horizons. The gap in adjusted $R^{2} \mathrm{~s}$ between PPP and the optimal factors becomes smaller as the horizon grows, and the optimal factors show better average predictive power again when the horizon reaches the two-year threshold. 


\section{B. Optimal Factors and PPP}

Next, we run the predictive regression (4) with optimal factors and an observable predictor. The chosen $Z_{t}$ in regression (3) is $q_{i, t}$. We select $q_{i, t}$ as the observable predictor for several reasons. Engel, Mark, and West (2007) report that PPP has the strongest ability to forecast exchange rate changes among alternative models. We also intend to check whether the optimal factors from the US macroeconomic series have additional predictive power for nominal exchange rate movements after controlling for $q_{i, t}$ as well as a synergy effect with $q_{i, t}$ in forecasting nominal exchange rate fluctuations. Finally, the real exchange rate might account for the economic status of non-US counterpart countries in bilateral exchange rates.

Again, optimal factors are determined by the BIC criterion; the frequencies selected are shown in Figure 4 for each horizon. The pattern is quite similar to that in Figure $3 . \hat{F}_{8 t}$ (comoving with money supply measures) is overwhelmingly the most frequently chosen at short horizons, from one to six months. However, $\hat{F}_{5 t}$ (comoving with US interest rate shortterm spread variables), $\widehat{F}_{4 t}$ (covarying with US interest rates), and $\widehat{F}_{1 t}$ (correlated with US employment conditions) become more frequently chosen at one- and two-year horizons. Moreover, $\hat{F}_{3 t}$ (related to US price indices) and $\hat{F}_{7 t}$ (related to US stock market variables) are rarely selected at any horizon, implying that US price sectors and stock market indicators have limited relationships with exchange rate fluctuations.

The adjusted $R^{2} \mathrm{~s}$ of the predictive regression with optimal factors and $q_{i, t}$ are presented in Table 3, along with those of the predictive regression with $q_{i, t}$ only. As shown in Table 3, the optimally chosen factors improve the adjusted $R^{2}$ s substantially. The adjusted 
$R^{2} \mathrm{~s}$ from all countries examined except Thailand improve with the inclusion of the optimal factors at a one-month horizon. At a two-year horizon, improvement in the adjusted $R^{2}$ can be observed in all countries: adjusted $R^{2}$ increases an average of $21 \%$ to $34 \%$ at this horizon. These results suggest that US macroeconomic variables have substantial predictive power for future nominal exchange rate movements in addition to the PPP relation. When $\sqrt{T}$ is comparable to $\sqrt{N}$, a bias may appear for the slope coefficients in the predictive regression, as discussed in Bai and $\mathrm{Ng}$ (2006). Hence, bias-corrected slope coefficients for the real exchange rate and optimal factors in predictive regressions for the one-month horizon are provided in Appendix Table A1. ${ }^{5}$ Consistent with the finding in Ludvigson and Ng (2010) that the bias is quite small for large $N$ and $T$, the bias-corrected slope coefficients and tstatistics are slightly changed. We also report test results for the hypothesis that all coefficients of macroeconomic factors in the predictive regressions are zero. As shown in Table 4, the null hypothesis is generally rejected at the conventional significance level; for example, the null hypothesis is rejected at the 5\% significance level for 21 countries at twoyear horizons. These results suggest that US macroeconomic factors are generally significant predictors of nominal exchange rates. ${ }^{6}$

Table 5 provides the results of running panel regressions that include the real exchange rate and eight factors together. To control for country-specific time-invariant factors, we employ the panel regression with fixed effect model. T-statistics based on serial correlation robust standard errors are shown for the real exchange rate and eight factors. First,

\footnotetext{
5 The bias-corrected slope coefficients for other horizons are available upon request.

${ }^{6}$ Chile, the Philippines, and South Africa are the only exceptions; in their cases, $H_{0}: \alpha_{F, i, h}=0$ has never been rejected for any horizon.
} 
$q_{i, t}$ has significantly negative coefficients for all horizons, meaning that the PPP fundamental has significant predictive power for future nominal exchange rates in 26 countries. Moreover, various factors have significant coefficients, and the number of significant factors tends to increase along with the horizon. $\hat{F}_{8 t}$ and $\widehat{F}_{6 t}$ together have significant coefficients for all horizons, and $R^{2}$ increases significantly compared to $R^{2}$ with only the real exchange rate considered at all horizons. These results indicate not only additional predictive power from the factors but also a strong synergy effect when both the real exchange rate and optimal factors are used together to predict nominal exchange rate changes.

\section{Predictive Regression: Out-of-sample Analysis}

In addition to the in-sample analysis, we conduct an out-of-sample analysis, a standard way to evaluate forecasting ability since Meese and Rogoff (1983). The initial sample period for the first forecast covers January 1973 to December 1992. The out-of-sample analysis is conducted as follows. First, we estimate US macroeconomic factors and factor loadings during the initial period. Then, we select optimal factors in the predictive regression with the real exchange rate using the BIC criterion. With the optimal factors and the real exchange rate, we make a forecast for $s_{t_{0}+h}-s_{t_{0}}$, where $t_{0}=$ December 1992, and calculate a forecast error. We repeat these steps to predict $s_{t_{0}+1+h}-s_{t_{0}+1}$ recursively after adding the next oneperiod observations of the real exchange rate and US macroeconomic data to our dataset at $t_{0}+1$. Forecast horizons are the same as those for the in-sample analyses.

The optimal factors selected by the BIC differ not only across horizons but also across time points when the forecasts are made. The finding that optimal factors vary across 
time points is similar to the report in Cheung and Chinn (2001) that foreign exchange traders' ranking of important macroeconomic variables shifts over time. Consistent with the results of the in-sample analysis, Figure 5 also shows that $\widehat{F}_{8 t}$ is the factor selected most frequently at a one-month horizon. As the forecast horizon increases, however, the frequency of the selection of $\hat{F}_{8 t}$ decreases, and $\hat{F}_{1 t}$ and $\hat{F}_{2 t}$ are the factors chosen most frequently at a two-year horizon. Unlike the results of the in-sample analysis, $\hat{F}_{3 t}$ and $\hat{F}_{7 t}$ are also selected with some frequency in the out-of-sample analysis. This result also implies that money supply measures are important in forecasting exchange rate changes in the short run, while variables indicating employment conditions and interest rate spreads make greater contributions in long-run predictions.

We compare the predictive power of the predictive regression augmented with the factors and PPP with that of the random walk model or PPP only. Clark-West (2007) statistics are employed for the evaluation of the predictive powers of the competing models. When the random walk model is compared, for example, the Clark-West adjusted U-statistics can be written as follows:

$$
\widetilde{U}_{i, h}^{(F, R)}=\frac{P^{-1} \sum_{t=1}^{P}\left(\widehat{\Delta s}_{i, t+h}^{F}-\Delta s_{i, t+h}\right)^{2}-P^{-1} \sum_{t=1}^{P}\left(\widehat{\Delta s}_{i, t+h}^{F}-\widehat{\Delta s}_{i, t+h}^{R}\right)^{2}}{P^{-1} \sum_{t=1}^{P}\left(\widehat{\Delta s}_{i, t+h}^{R}-\Delta s_{i, t+h}\right)^{2}}
$$

where superscript $F$ indicates the factor-PPP augmented model, superscript $R$ is a random walk model, and $P$ is the number of forecasts. The null hypothesis is that the two competing forecasting models have an equal mean squared prediction error, whereas the alternative hypothesis is that the larger model (the factor-PPP augmented model) has a smaller mean squared prediction error. Due to the possible serial correlation among forecast errors, Newey- 
West standard errors are employed for the test.

Table 6 shows the Clark-West adjusted U-statistics against the random walk model. Bold font numbers indicate that the null hypothesis of the equal mean squared prediction error is rejected at a $10 \%$ or higher significance level. The factor-PPP augmented model shows a significantly smaller mean squared prediction error than the random walk model in all countries except Korea, New Zealand, and Thailand at a one-month horizon. As the horizon increases, a similar pattern continues, and the factor-PPP augmented model has a significantly smaller mean squared prediction error than the random walk model in all countries at a two-year horizon. ${ }^{7}$

We also test the equal predictive accuracy between the factor-PPP augmented model and the PPP model in Table 7. As shown in the first column of Table 7, the factor-PPP augmented model significantly outperforms the PPP model in 22 countries out of 26 at a onemonth forecast horizon. At three- and six-month horizons, the adjusted Clark-West U statistics are significantly smaller than one in approximately half the countries. However, the rejection rate increases with the horizon again, and the null hypothesis is rejected at a $10 \%$ or higher level in 19 countries at a two-year horizon.

\section{Forecasting Exchange Rate with US Macroeconomic Factors and Domestic Macroeconomic Factors}

\footnotetext{
7 One possible reason for the poor out-of-sample predictive power of Korea and Thailand is that the exchange rate system became completely floating (Korea) or managed-floating (Thailand) only after Asian crisis.
} 
We have shown that US macroeconomic factors have substantial predictive power for bilateral exchange rates with or without conditioning on PPP. In examining the predictive ability of US macroeconomic factors, we have not considered the economic conditions of counterpart economies. It would be interesting to evaluate the forecast ability of macroeconomic factors extracted not only from a panel of US macroeconomic series but also from a panel of a counterpart economy's macroeconomic series to examine the connection between the exchange rate and macroeconomic variables. We thus run the following regression:

$$
\Delta s_{i, t+h}=\alpha_{0, i}+\alpha_{F, h}^{\prime} \hat{f}_{t}+\alpha_{d F, i, h}^{\prime} \widehat{d f}_{i, t}+\varepsilon_{i, t+h}
$$

where $\widehat{d f}_{i, t}$ denotes an estimate of the macroeconomic factors from a large panel of time series data for the counterpart economy.

Due to data accessibility issues, we examine regression (6) using the Korea-US bilateral exchange rate, a panel of macroeconomic data for Korea, and a panel of macroeconomic data for the US. A total of 215 macroeconomic series of Korea are obtained from the dataset managed by the Bank of Korea (BOK) and the National Statistical Office. ${ }^{8}$ The large macroeconomic dataset constructed for Korea contains information on various aspects of the Korean economy, such as domestic construction, industry production, inventory, sales, unemployment, housing market, export, import, monetary base, interest rates, price indices, and stock market indices. Because exchange rates in Korea became completely floating from January 1998, we focus on the period between January 1998 and December

\footnotetext{
${ }^{8}$ The dataset managed by the BOK can be found at http://ecos.bok.or.kr/. The dataset managed by the National Statistical Office can be found at http://kosis.kr/. The panel of Korean macroeconomic series does not include exchange rates, in accordance with that for the US.
} 
2011. Over this period, four macroeconomic factors are estimated from the 215 macroeconomic series for Korea. $\widehat{D F}_{1 t}$ has a high correlation, at almost one, with the export value index; $\widehat{D F}_{2 t}$ is positively correlated with domestic construction orders; $\widehat{D F}_{3 t}$ has a positive correlation with the market interest rate (the yield on CP); and $\widehat{D F}_{4 t}$ comoves with the manufacturing operation ratio index.

Optimal factors among the estimated Korean and US factors are selected by the BIC in the predictive regression. Table 8 compares the results from the predictive regressions with the real exchange rate only, with US macroeconomic factors, and with US and Korean macroeconomic factors. As shown in Table 8, the predictive regressions with US macroeconomic factors have higher adjusted $R^{2}$ than in the PPP model, except for the onemonth horizon. When Korean macroeconomic factors are added, however, the adjusted $R^{2}$ improves substantially for all horizons, implying that the macroeconomic variables from both economies have significant predictive power for movements in the bilateral exchange rate. Similar to the results in previous sections, the factors chosen by the BIC differ across horizons. For example, $\widehat{D F}_{4 t}$, comoving with the manufacturing operation ratio index, is often selected over short horizons, while $\widehat{D F}_{3 t}$, related to the market interest rate, replaces $\widehat{D F}_{4 t}$ at long horizons.

Finally, we compare the out-of-sample performance of Equation (6) with that of the random walk model and the PPP in Table 9. We employ the Clark-West adjusted U-statistics to test the null hypothesis of the equal predictability between Equation (6) and the random walk model and the Diebold-Mariano test statistics to test the same null hypothesis between 
Equation (6) and PPP. ${ }^{9}$ As shown in Table 9, Equation (6) shows more accurate predictability than the random walk at all horizons, and those differences are significant at the $5 \%$ level. In the comparison between Equation (6) and PPP, Equation (6) shows slightly better predictability than PPP at one- and two-year horizons, but none is significant. We then add the real exchange rate to Equation (6) and compare out-of-sample predictive power between Equation (6) augmented with the real exchange rate and the random walk model and PPP. As shown in the last two panels of Table 9, the addition of the real exchange rate greatly enhances the predictive power of Equation (6). As a result, Equation (6) augmented with the real exchange rate shows significantly more precise out-of-sample predictive power than the random walk model or the PPP at all horizons according to the Clark-West adjusted Ustatistics.

\section{Conclusion}

Many studies in international finance have tried to relate exchange rates to macroeconomic variables. Some have succeeded in finding a significant relation between the two, whereas others have not. We use a large panel of US macroeconomic series to see whether bilateral US dollar exchange rates are explained by US macroeconomic variables. Utilizing the factoraugmented predictive regression, we find that factors extracted from US macroeconomic data have significant predictive power for fluctuations in the nominal exchange rate and can substantially improve the predictive power of the PPP through both in-sample and out-ofsample analyses. Furthermore, factors estimated from the large panels of Korean and US

\footnotetext{
${ }^{9}$ Since PPP is not nested with Equation (6), we use the Diebold-Mariano test statistics instead of the ClarkWest U-statistics for the comparison.
} 
macroeconomic variables show excellent predictive power for movements in the Korea-US bilateral exchange rate. Overall, this evidence strongly suggests that the exchange rate is not disconnected from a large panel of macroeconomic variables.

Moreover, we find that the factors frequently chosen to predict short-run movements in the exchange rate are not necessarily the factors most often selected to predict long-run movements and that optimal factors selected by the BIC in the out-of-sample analysis differ greatly depending on the time points when the forecasts are made. These findings can explain why the few macroeconomic variables selected in previous studies have sensitive forecast abilities depending on the sample period, forecast horizon, and other conditions. The findings suggest that, even if there is a stable relation between the exchange rate and a large panel of macroeconomic variables, that relation cannot be clearly seen between the exchange rate and a few selected variables as the sample period or forecast horizon changes. This might be due to the finding in Cheung and Chinn (2001) that currency traders use different models and macroeconomic variables over time to understand exchange rate movements, or due to the consequence of the scapegoat effect described in Bacchetta and Van Wincoop (2013). Further investigation in this direction would be an interesting future research project. 


\section{References}

Bacchetta, Philippe, and Eric van Wincoop. 2013. “On the Unstable Relationship between Exchange Rates and Macroeconomic Fundamentals,” Journal of International Economics 91 (1): 18-26.

Bai, Jushan, and Serena Ng. 2002. "Determining the Number of Factors in Approximate Factor Models.” Econometrica 70 (1): 191-221.

Bai, Jushan, and Serena Ng. 2006. "Confidence Intervals for Diffusion Index Forecasts and Inference for Factor-Augmented Regressions.” Econometrica 74 (4): 1133-50.

Berkowitz, Jeremy, and Lorenzo Giorgianni. 2001. “Long-Horizon Exchange Rate Predictability?” The Review of Economics and Statistics 83: 81-91.

Cheung, Yin-Wong, and Menzie David Chinn. 2001. "Currency traders and exchange rate dynamics: A survey of the US market.” Journal of International Money and Finance 20: 439-471.

Chinn, Menzie D. and Richard A. Meese. 1995. "Banking on Currency Forecasts: How Predictable is Change in Money?” Journal of International Economics 38: 161-178.

Clark, Todd E. and Kenneth D._West. 2006. “Approximately Normal Tests for Equal Predictive Accuracy in Nested Models.” Journal of Econometrics 138: 291-311.

Engel, Charles, Nelson C. Mark and Kenneth D. West. 2008. "Exchange Rate Models Are Not As Bad As You Think.” In: Acemoglu, D., Rogoff, K., Woodford, M., eds. NBER Macroeconomics Annual 2007, University of Chicago Press, pp. 381-441.

Engel, Charles, Nelson C. Mark and Kenneth D. West. 2014. "Factor Model Forecasts of Exchange Rates." Econometric Reviews 34: 32-55.

Greenway-McGrevy, Ryan, Nelson C. Mark, Donggyu Sul, and Jyh-Lin Wu. 2015. "Identifying Exchange Rate Common Factors.” Working paper

Jurado, Kyle, Sydney C. Ludvigson, and Serena Ng. 2015. “Measuring Uncertainty” American Economic Review 105 (3): 1177-1216.

Kilian, Lutz. 1999. "Exchange Rates and Monetary Fundamentals: What Do We Learn from LongHorizon Regressions?” Journal of Applied Econometrics 14: 491-510.

Ludvigson, Sydney C., and Serena Ng. 2009. "Macro Factors in Bond Risk Premia.” Review of Financial Studies 22 (12): 5027-67.

Ludvigson, Sydney C., and Serena Ng. 2010. “A Factor Analysis of Bond Risk Premia.” In: Uhla, A. and Giles, D.E.A., eds. Handbook of Empirical Economics and Finance, Chapman and Hall, Boca Raton, pp. 313-372

Mark, Nelson C. 1995. "Exchange Rates and Fundamentals: Evidence on Long-Horizon Predictability.” American Economic Review 85: 201-218. 
Meese, Richard A. and Kenneth Rogoff. 1983. "Empirical Exchange Rate Models of Seventies: Do They Fit Out-of-sample?” Journal of International Economics 14: 3-24.

Moench, Emanuel. 2008. "Forecasting the Yield Curve in a Data-rich Environment: A No-arbitrage Factor-augmented VAR Approach.” Journal of Econometrics 146: 26-43.

Obstfeld, Maurice, and Kenneth Rogoff. 2001. "The Six Major Puzzles in International Macroeconomics: Is There a Common Cause?” In: Bernanke, B., and Rogoff, K., eds. NBER Macroeconomics Annual 2000, MIT Press, pp._339-412.

Park, Cheolbeom, and Sookyung Park. 2013. "Exchange Rate Predictability and a Monetary Model with Time-varying Cointegration Coefficients.” Journal of International Money and Finance 37: 394410.

Stock, James H., and Mark W. Watson. 2002. "Forecasting Using Principal Components from a Large Number of Predictors.” Journal of the American Statistical Association 97 (460): 1167-79.

Stock, James H., and Mark W. Watson. 2006. “Forecasting with Many Predictors.” In: Pesaran, H.M. and Weale, M., eds. Handbook of Forecasting, Amsterdam, Elsevier, pp. 515-54. 
Table 1. Descriptive Statistics for Estimated Factors

\begin{tabular}{|l|c|c|}
\hline & AR(1) coefficient & Cumulative R-squared \\
\hline$\hat{F}_{1 t}$ & 0.81 & 0.19 \\
\hline$\hat{F}_{2 t}$ & 0.64 & 0.26 \\
\hline$\hat{F}_{3 t}$ & -0.02 & 0.34 \\
\hline$\hat{F}_{4 t}$ & 0.46 & 0.40 \\
\hline$\hat{F}_{5 t}$ & 0.57 & 0.45 \\
\hline$\hat{F}_{6 t}$ & 0.47 & 0.49 \\
\hline$\hat{F}_{7 t}$ & 0.20 & 0.52 \\
\hline$\hat{F}_{8 t}$ & -0.10 & 0.54 \\
\hline
\end{tabular}

Notes: $\hat{F}_{i t}$ are factors found by $I C_{2}$ criterion applied to 127 US macroeconomic series. 
Table 2. Adjusted $R^{2}$ from Factor-augmented Predictive Regressions: Optimal Macroeconomic Factors Only

\begin{tabular}{|l|c|c|c|c|c|}
\hline & \multicolumn{5}{|l}{ Optimal Macroeconomic Factors only } \\
\hline \multicolumn{1}{|c|}{ Horizon } & 1 month & 3 month & 6 months & 12 months & 24 months \\
\hline 1. Australia & 0.014 & 0.007 & 0.009 & 0.063 & 0.205 \\
\hline 2. Canada & 0.016 & 0.016 & 0.009 & 0.027 & 0.161 \\
\hline 3. Chile & 0.047 & 0.068 & 0.079 & 0.137 & 0.181 \\
\hline 4. Colombia & 0.009 & 0.014 & 0.033 & 0.082 & 0.138 \\
\hline 5. Denmark & 0.013 & 0.014 & 0.033 & 0.113 & 0.250 \\
\hline 6. Iceland & 0.039 & 0.119 & 0.187 & 0.272 & 0.426 \\
\hline 7. Japan & 0.008 & 0.019 & 0.037 & 0.057 & 0.061 \\
\hline 8. Korea & 0.004 & 0.010 & 0.051 & 0.109 & 0.178 \\
\hline 9. New Zealand & 0.010 & 0.019 & 0.039 & 0.111 & 0.316 \\
\hline 10. Norway & 0.014 & 0.020 & 0.013 & 0.049 & 0.223 \\
\hline 11. Philippines & 0.004 & 0.002 & 0.003 & 0.006 & 0.085 \\
\hline 12. Singapore & 0.007 & 0.015 & 0.012 & 0.016 & 0.013 \\
\hline 13. South Africa & 0.007 & 0.004 & 0.005 & 0.028 & 0.155 \\
\hline 14. Sweden & 0.010 & 0.014 & 0.016 & 0.057 & 0.267 \\
\hline 15. Switzerland & 0.006 & 0.007 & 0.004 & 0.006 & 0.045 \\
\hline 16. Thailand & -0.001 & 0.000 & 0.002 & 0.015 & 0.044 \\
\hline 17. UK & 0.006 & 0.025 & 0.037 & 0.115 & 0.392 \\
\hline 18. Austria & 0.013 & 0.009 & 0.011 & 0.071 & 0.193 \\
\hline 19. Belgium & 0.013 & 0.013 & 0.032 & 0.125 & 0.270 \\
\hline 20. Finland & 0.015 & 0.007 & 0.014 & 0.081 & 0.267 \\
\hline 21. France & 0.014 & 0.019 & 0.045 & 0.095 & 0.285 \\
\hline 22. Germany & 0.014 & 0.011 & 0.013 & 0.091 & 0.201 \\
\hline 23. Italy & 0.013 & 0.017 & 0.040 & 0.115 & 0.332 \\
\hline 24. Netherlands & 0.013 & 0.012 & 0.024 & 0.074 & 0.204 \\
\hline 25. Portugal & 0.023 & 0.031 & 0.042 & 0.084 & 0.255 \\
\hline 26. Spain & 0.009 & 0.011 & 0.033 & 0.102 & 0.320 \\
\hline Average & 0.013 & 0.019 & 0.032 & 0.081 & 0.210 \\
\hline
\end{tabular}

Notes: The table shows adjusted $R^{2}$ from the regression of $\Delta s_{i, t+h}=\alpha_{0, i}+\alpha_{F, i, h}^{\prime} \hat{f}_{t}+\varepsilon_{i, t+h}$ where $\hat{f}_{t}$ denotes estimated US macroeconomic factors. 
Table 3. Adjusted $R^{2}$ from Factor-augmented Predictive Regressions: PPP only and PPP and Optimal Factors

\begin{tabular}{|c|c|c|c|c|c|c|c|c|c|c|}
\hline Horizons & \multicolumn{2}{|c|}{1 month } & \multicolumn{2}{|c|}{3 month } & \multicolumn{2}{|c|}{6 months } & \multicolumn{2}{|c|}{12 months } & \multicolumn{2}{|c|}{24 months } \\
\hline $\begin{array}{l}\text { Predictive } \\
\text { regression }\end{array}$ & PPP & $\begin{array}{c}\text { PPP } \\
\text { and US } \\
\text { Factors }\end{array}$ & PPP & $\begin{array}{c}\text { PPP } \\
\text { and US } \\
\text { Factors }\end{array}$ & PPP & $\begin{array}{c}\text { PPP } \\
\text { and US } \\
\text { Factors }\end{array}$ & PPP & $\begin{array}{c}\text { PPP } \\
\text { and US } \\
\text { Factors }\end{array}$ & PPP & $\begin{array}{c}\text { PPP } \\
\text { and US } \\
\text { Factors }\end{array}$ \\
\hline 1. Australia & 0.003 & 0.016 & 0.015 & 0.022 & 0.033 & 0.044 & 0.074 & 0.118 & 0.188 & 0.259 \\
\hline 2. Canada & 0.005 & 0.031 & 0.017 & 0.030 & 0.037 & 0.044 & 0.076 & 0.085 & 0.183 & 0.240 \\
\hline 3. Chile & 0.054 & 0.081 & 0.170 & 0.191 & 0.249 & 0.280 & 0.260 & 0.312 & 0.234 & 0.303 \\
\hline 4. Colombia & -0.001 & 0.007 & 0.003 & 0.020 & 0.010 & 0.033 & 0.025 & 0.091 & 0.073 & 0.145 \\
\hline 5. Denmark & 0.004 & 0.017 & 0.016 & 0.026 & 0.035 & 0.063 & 0.079 & 0.152 & 0.202 & 0.379 \\
\hline 6. Iceland & 0.006 & 0.051 & 0.024 & 0.122 & 0.045 & 0.200 & 0.113 & 0.310 & 0.180 & 0.458 \\
\hline 7. Japan & 0.002 & 0.013 & 0.011 & 0.065 & 0.028 & 0.100 & 0.065 & 0.173 & 0.185 & 0.355 \\
\hline 8. Korea & 0.016 & 0.022 & 0.057 & 0.069 & 0.117 & 0.135 & 0.239 & 0.286 & 0.441 & 0.484 \\
\hline 9. New Zealand & 0.000 & 0.010 & 0.004 & 0.023 & 0.015 & 0.041 & 0.054 & 0.139 & 0.155 & 0.382 \\
\hline 10. Norway & 0.007 & 0.021 & 0.027 & 0.045 & 0.054 & 0.065 & 0.093 & 0.109 & 0.162 & 0.296 \\
\hline 11. Philippines & 0.003 & 0.006 & 0.014 & 0.015 & 0.032 & 0.035 & 0.076 & 0.086 & 0.178 & 0.230 \\
\hline 12. Singapore & 0.007 & 0.013 & 0.023 & 0.049 & 0.044 & 0.111 & 0.081 & 0.136 & 0.201 & 0.267 \\
\hline 13. South Africa & 0.004 & 0.009 & 0.020 & 0.022 & 0.047 & 0.048 & 0.100 & 0.108 & 0.233 & 0.246 \\
\hline 14. Sweden & 0.007 & 0.014 & 0.025 & 0.035 & 0.060 & 0.070 & 0.127 & 0.149 & 0.271 & 0.377 \\
\hline 15. Switzerland & 0.007 & 0.017 & 0.028 & 0.044 & 0.051 & 0.061 & 0.114 & 0.140 & 0.272 & 0.375 \\
\hline 16. Thailand & 0.004 & 0.004 & 0.018 & 0.021 & 0.039 & 0.041 & 0.084 & 0.095 & 0.160 & 0.175 \\
\hline 17. UK & 0.010 & 0.015 & 0.041 & 0.050 & 0.086 & 0.094 & 0.166 & 0.211 & 0.303 & 0.521 \\
\hline 18. Austria & 0.006 & 0.020 & 0.025 & 0.033 & 0.048 & 0.061 & 0.099 & 0.163 & 0.235 & 0.372 \\
\hline 19. Belgium & 0.002 & 0.015 & 0.012 & 0.022 & 0.029 & 0.042 & 0.066 & 0.159 & 0.187 & 0.361 \\
\hline 20. Finland & 0.008 & 0.022 & 0.029 & 0.034 & 0.062 & 0.069 & 0.127 & 0.168 & 0.278 & 0.394 \\
\hline 21. France & 0.006 & 0.019 & 0.023 & 0.033 & 0.053 & 0.081 & 0.114 & 0.171 & 0.256 & 0.421 \\
\hline 22. Germany & 0.006 & 0.020 & 0.024 & 0.031 & 0.051 & 0.062 & 0.108 & 0.150 & 0.258 & 0.364 \\
\hline 23. Italy & 0.002 & 0.015 & 0.011 & 0.023 & 0.027 & 0.058 & 0.063 & 0.139 & 0.150 & 0.381 \\
\hline 24. Netherlands & 0.005 & 0.017 & 0.022 & 0.030 & 0.046 & 0.057 & 0.098 & 0.137 & 0.239 & 0.351 \\
\hline 25. Portugal & -0.001 & 0.021 & 0.000 & 0.031 & 0.001 & 0.043 & 0.003 & 0.086 & -0.002 & 0.254 \\
\hline 26. Spain & 0.000 & 0.009 & 0.004 & 0.012 & 0.012 & 0.040 & 0.036 & 0.130 & 0.114 & 0.345 \\
\hline Average & 0.007 & 0.019 & 0.025 & 0.042 & 0.050 & 0.076 & 0.098 & 0.154 & 0.205 & 0.336 \\
\hline
\end{tabular}

Notes: The table compares adjusted $R^{2}$ s from the regression of $\Delta s_{i, t+h}=\alpha_{0, i}+\alpha_{Z, i, h}^{\prime} q_{i t}+$ $\varepsilon_{i, t+h}$ and from the regression of $\Delta s_{i, t+h}=\alpha_{0, i}+\alpha_{F, i, h}^{\prime} \hat{f}_{t}+\alpha_{Z, i, h}^{\prime} q_{i t}+\varepsilon_{i, t+h}$ where $\hat{f}_{t}$ is estimated US macroeconomic factors. 
Table 4. Joint Test Results of Macro Factors in Factor-augmented PPP Model

\begin{tabular}{|c|c|c|c|c|c|c|c|c|c|c|}
\hline & \multicolumn{2}{|c|}{1 month } & \multicolumn{2}{|c|}{3 month } & \multicolumn{2}{|c|}{6 months } & \multicolumn{2}{|c|}{12 months } & \multicolumn{2}{|c|}{24 months } \\
\hline & $\begin{array}{c}\text { Wald } \\
\text { Stat }\end{array}$ & $p$-value & $\begin{array}{c}\text { Wald } \\
\text { Stat }\end{array}$ & $p$-value & $\begin{array}{c}\text { Wald } \\
\text { Stat }\end{array}$ & $\mathrm{p}$-value & $\begin{array}{c}\text { Wald } \\
\text { Stat }\end{array}$ & $\mathrm{p}$-value & $\begin{array}{c}\text { Wald } \\
\text { Stat }\end{array}$ & $p$-value \\
\hline 1. Australia & 5.36 & 0.0206 & 2.21 & 0.1369 & 2.32 & 0.1280 & 6.11 & 0.1065 & 19.03 & 0.0003 \\
\hline 2. Canada & 4.34 & 0.1144 & 3.81 & 0.0510 & 2.30 & 0.1295 & 0.80 & 0.3714 & 12.70 & 0.0053 \\
\hline 3. Chile & 2.00 & 0.1569 & 2.44 & 0.1184 & 4.52 & 0.1044 & 1.91 & 0.3857 & 1.37 & 0.5046 \\
\hline 4. Colombia & 6.48 & 0.0109 & 5.31 & 0.0212 & 4.06 & 0.0440 & 10.40 & 0.0154 & 8.71 & 0.0688 \\
\hline 5. Denmark & 3.20 & 0.0738 & 3.39 & 0.0656 & 6.30 & 0.0429 & 11.27 & 0.0103 & 27.81 & 0.0000 \\
\hline 6. Iceland & 12.41 & 0.0020 & 31.12 & 0.0000 & 48.18 & 0.0000 & 46.07 & 0.0000 & 39.13 & 0.0000 \\
\hline 7. Japan & 5.96 & 0.0146 & 20.08 & 0.0002 & 17.00 & 0.0002 & 14.84 & 0.0020 & 34.58 & 0.0000 \\
\hline 8. Korea & 1.34 & 0.2466 & 2.96 & 0.0853 & 3.04 & 0.0812 & 9.63 & 0.0220 & 7.87 & 0.0196 \\
\hline 9. New Zealand & 3.13 & 0.0771 & 5.62 & 0.0178 & 4.96 & 0.0260 & 33.74 & 0.0000 & 79.30 & 0.0000 \\
\hline 10. Norway & 2.93 & 0.0868 & 4.90 & 0.0269 & 3.78 & 0.0519 & 2.68 & 0.1018 & 19.01 & 0.0003 \\
\hline 11. Philippines & 2.56 & 0.1093 & 1.31 & 0.2530 & 0.81 & 0.3688 & 2.92 & 0.0874 & 4.75 & 0.1909 \\
\hline 12. Singapore & 2.36 & 0.1243 & 9.41 & 0.0022 & 12.85 & 0.0050 & 9.93 & 0.0070 & 14.48 & 0.0128 \\
\hline 13. South Africa & 0.61 & 0.4360 & 1.61 & 0.2045 & 0.33 & 0.5673 & 1.91 & 0.1675 & 1.05 & 0.3058 \\
\hline 14. Sweden & 1.81 & 0.1784 & 4.50 & 0.0339 & 3.57 & 0.0589 & 2.10 & 0.3508 & 12.31 & 0.0152 \\
\hline 15. Switzerland & 4.37 & 0.0366 & 5.52 & 0.0188 & 1.76 & 0.1851 & 3.05 & 0.2172 & 29.98 & 0.0000 \\
\hline 16. Thailand & 1.67 & 0.1958 & 1.97 & 0.1599 & 1.63 & 0.2014 & 3.44 & 0.0637 & 2.62 & 0.1053 \\
\hline 17. UK & 3.82 & 0.0506 & 2.95 & 0.0858 & 3.38 & 0.0661 & 10.03 & 0.0066 & 28.94 & 0.0000 \\
\hline 18. Austria & 3.88 & 0.0487 & 3.21 & 0.0730 & 4.14 & 0.0420 & 11.55 & 0.0210 & 29.71 & 0.0000 \\
\hline 19. Belgium & 3.71 & 0.0542 & 3.58 & 0.0586 & 4.19 & 0.0406 & 12.55 & 0.0137 & 20.46 & 0.0010 \\
\hline 20. Finland & 3.73 & 0.0535 & 2.75 & 0.0971 & 3.49 & 0.0616 & 7.01 & 0.0300 & 24.29 & 0.0001 \\
\hline 21. France & 3.70 & 0.0543 & 3.12 & 0.0774 & 6.31 & 0.0426 & 8.49 & 0.0368 & 15.87 & 0.0072 \\
\hline 22. Germany & 3.92 & 0.0478 & 3.02 & 0.0825 & 3.85 & 0.0497 & 6.85 & 0.0325 & 17.58 & 0.0035 \\
\hline 23. Italy & 3.81 & 0.0510 & 3.99 & 0.0459 & 7.30 & 0.0260 & 13.50 & 0.0037 & 58.60 & 0.0000 \\
\hline 24. Netherlands & 3.68 & 0.0552 & 3.23 & 0.0722 & 3.73 & 0.0533 & 7.09 & 0.0289 & 25.79 & 0.0001 \\
\hline 25. Portugal & 6.25 & 0.0124 & 8.69 & 0.0130 & 9.85 & 0.0073 & 15.06 & 0.0005 & 42.38 & 0.0000 \\
\hline 26. Spain & 2.96 & 0.0851 & 3.73 & 0.0535 & 6.98 & 0.0306 & 14.90 & 0.0049 & 33.33 & 0.0000 \\
\hline
\end{tabular}

Notes: This table shows test results for $H_{0}: \alpha_{F, i, h}=0$ in the regression of $\Delta s_{i, t+h}=\alpha_{0, i}+$ $\alpha_{F, i, h}^{\prime} \hat{f}_{t}+\alpha_{Z, i, h}^{\prime} q_{i t}+\varepsilon_{i, t+h}$ where $\hat{f}_{t}$ denotes estimated US macroeconomic factors. 
Table 5. Factor Augmented Predictive Regression: Panel Regression

\begin{tabular}{|c|c|c|c|c|c|c|c|c|c|c|}
\hline predictive & \multicolumn{2}{|c|}{1 month } & \multicolumn{2}{|c|}{3 month } & \multicolumn{2}{|c|}{6 months } & \multicolumn{2}{|c|}{12 months } & \multicolumn{2}{|c|}{24 months } \\
\hline Model & PPP & $\begin{array}{c}\text { PPP and } \\
\text { US } \\
\text { Factors }\end{array}$ & PPP & $\begin{array}{l}\text { PPP and } \\
\text { US } \\
\text { Factors }\end{array}$ & PPP & $\begin{array}{c}\text { PPP and } \\
\text { US } \\
\text { Factors } \\
\end{array}$ & PPP & $\begin{array}{l}\text { PPP and } \\
\text { US } \\
\text { Factors } \\
\end{array}$ & PPP & $\begin{array}{c}\text { PPP and } \\
\text { US } \\
\text { Factors }\end{array}$ \\
\hline$q_{i t}$ & $-0.019 * * *$ & $-0.017 * * *$ & $-0.065 * * *$ & $-0.065 * * *$ & $-0.135 * * *$ & $-0.130 * * *$ & $-0.257 * * *$ & $-0.232 * * *$ & $-3.359 * * *$ & $-2.754 * * *$ \\
\hline$\hat{F}_{1 t}$ & & $-0.001^{*}$ & & $-0.002 *$ & & $-0.003^{* *}$ & & $-0.006^{* *}$ & & -0.038 \\
\hline$\hat{F}_{2 t}$ & & $-0.001^{* *}$ & & -0.002 & & $-0.005^{*}$ & & $-0.011 * *$ & & $-0.159 * * *$ \\
\hline$\hat{F}_{3 t}$ & & -0.000 & & $-0.003 * * *$ & & $-0.005^{* * *}$ & & $-0.006 * * *$ & & $-0.070 * * *$ \\
\hline$\hat{F}_{4 t}$ & & -0.000 & & $-0.003 * * *$ & & -0.002 & & -0.000 & & $0.125^{* * *}$ \\
\hline$\hat{F}_{5 t}$ & & -0.000 & & -0.002 & & -0.004 & & $-0.017 * * *$ & & $-0.335 * * *$ \\
\hline$\hat{F}_{6 t}$ & & $0.001 * * *$ & & $0.002 * * *$ & & $0.005^{* * *}$ & & $-0.010 * * *$ & & $0.106 * * *$ \\
\hline$\hat{F}_{7 t}$ & & $0.001 * * *$ & & 0.000 & & 0.001 & & $0.000 *$ & & 0.012 \\
\hline & & $0.003^{* * *}$ & & $0.004 * * *$ & & $0.007 * * *$ & & $0.011 * * *$ & & $0.107 * * *$ \\
\hline Within $\mathrm{R}^{2}$ & 0.009 & 0.0196 & 0.0301 & 0.0429 & 0.0561 & 0.0712 & 0.0943 & 0.1255 & 0.1391 & 0.2085 \\
\hline Within $\overline{\mathrm{R}^{2}}$ & 0.0069 & 0.0168 & 0.028 & 0.0402 & 0.0541 & 0.0686 & 0.0924 & 0.123 & 0.1372 & 0.2062 \\
\hline
\end{tabular}

Notes: The table shows the results of the panel factor augmented predictive regression, which is $\Delta s_{i, t+h}=\alpha_{0, i}+\alpha_{F, h}^{\prime} \hat{f}_{t}+\alpha_{Z, h}^{\prime} q_{i t}+\varepsilon_{i, t+h}$ where $\hat{f}_{t}$ denotes estimated US macroeconomic factors. ${ }^{*}, * *$, and $* * *$ denote that each null hypothesis can be rejected at significance levels of $10 \%, 5 \%$, and $1 \%$, respectively. 
Table 6. Out-of-Sample Analysis: Optimal Factors and PPP vs. Random Walk

\begin{tabular}{|l|r|r|r|r|r|}
\hline & 1 month & 3 month & 6 months & 12 months & 24 months \\
\hline 1. Australia & $\mathbf{0 . 9 6 2}$ & $\mathbf{0 . 9 5 9}$ & $\mathbf{0 . 9 5 4}$ & $\mathbf{0 . 8 8 7}$ & $\mathbf{0 . 6 9 3}$ \\
2. Canada & 0.990 & $\mathbf{0 . 9 5 6}$ & $\mathbf{0 . 9 6 9}$ & $\mathbf{0 . 9 2 6}$ & $\mathbf{0 . 8 1 0}$ \\
3. Chile & $\mathbf{0 . 6 6 6}$ & $\mathbf{0 . 2 8 7}$ & $\mathbf{0 . 1 7 5}$ & $\mathbf{- 0 . 0 7 6}$ & $\mathbf{- 0 . 0 9 1}$ \\
4. Colombia & $\mathbf{0 . 9 8 5}$ & 0.994 & 0.990 & 0.997 & $\mathbf{0 . 9 4 9}$ \\
5. Denmark & $\mathbf{0 . 9 4 2}$ & $\mathbf{0 . 9 6 2}$ & $\mathbf{0 . 9 0 7}$ & $\mathbf{0 . 7 2 5}$ & $\mathbf{0 . 4 0 1}$ \\
6. Iceland & $\mathbf{0 . 8 6 5}$ & $\mathbf{0 . 7 7 6}$ & $\mathbf{0 . 6 2 1}$ & $\mathbf{0 . 4 1 0}$ & $\mathbf{0 . 0 8 7}$ \\
7. Japan & $\mathbf{0 . 9 6 0}$ & $\mathbf{0 . 9 5 2}$ & $\mathbf{0 . 9 0 5}$ & $\mathbf{0 . 7 9 6}$ & $\mathbf{0 . 5 9 4}$ \\
8. Korea & 0.980 & $\mathbf{0 . 9 1 9}$ & $\mathbf{0 . 8 2 3}$ & $\mathbf{0 . 6 2 3}$ & $\mathbf{0 . 1 0 6}$ \\
9. New Zealand & 0.990 & $\mathbf{0 . 9 7 9}$ & $\mathbf{0 . 9 7 4}$ & $\mathbf{0 . 8 6 7}$ & $\mathbf{0 . 5 2 6}$ \\
10. Norway & $\mathbf{0 . 9 5 6}$ & $\mathbf{0 . 9 3 1}$ & $\mathbf{0 . 9 1 1}$ & $\mathbf{0 . 8 6 8}$ & $\mathbf{0 . 6 7 8}$ \\
11. Philippines & $\mathbf{0 . 9 7 7}$ & $\mathbf{0 . 9 6 7}$ & $\mathbf{0 . 9 3 7}$ & $\mathbf{0 . 8 1 4}$ & $\mathbf{0 . 4 2 4}$ \\
12. Singapore & $\mathbf{0 . 9 4 4}$ & $\mathbf{0 . 8 7 5}$ & $\mathbf{0 . 8 3 6}$ & $\mathbf{0 . 8 2 7}$ & $\mathbf{0 . 6 4 9}$ \\
13. South Africa & $\mathbf{0 . 9 6 7}$ & $\mathbf{0 . 9 6 8}$ & $\mathbf{0 . 9 6 8}$ & 0.980 & $\mathbf{0 . 7 6 0}$ \\
14. Sweden & $\mathbf{0 . 9 6 0}$ & $\mathbf{0 . 9 3 5}$ & $\mathbf{0 . 8 7 6}$ & $\mathbf{0 . 8 1 6}$ & $\mathbf{0 . 5 3 2}$ \\
15. Switzerland & $\mathbf{0 . 9 7 7}$ & $\mathbf{0 . 9 3 4}$ & $\mathbf{0 . 9 0 2}$ & $\mathbf{0 . 8 2 8}$ & $\mathbf{0 . 4 9 4}$ \\
16. Thailand & 1.034 & 1.023 & $\mathbf{0 . 9 4 9}$ & $\mathbf{0 . 8 6 9}$ & $\mathbf{0 . 7 5 9}$ \\
17. UK & $\mathbf{0 . 9 3 7}$ & $\mathbf{0 . 9 1 1}$ & $\mathbf{0 . 8 4 5}$ & $\mathbf{0 . 6 9 6}$ & $\mathbf{0 . 3 2 5}$ \\
18. Austria & $\mathbf{0 . 9 4 2}$ & $\mathbf{0 . 9 3 8}$ & $\mathbf{0 . 8 7 7}$ & $\mathbf{0 . 7 3 1}$ & $\mathbf{0 . 4 2 0}$ \\
19. Belgium & $\mathbf{0 . 9 5 0}$ & $\mathbf{0 . 9 7 7}$ & $\mathbf{0 . 9 3 3}$ & $\mathbf{0 . 7 5 8}$ & $\mathbf{0 . 5 3 9}$ \\
20. Finland & $\mathbf{0 . 9 5 1}$ & $\mathbf{0 . 9 3 8}$ & $\mathbf{0 . 8 9 9}$ & $\mathbf{0 . 8 3 1}$ & $\mathbf{0 . 4 5 9}$ \\
21. France & $\mathbf{0 . 9 4 9}$ & $\mathbf{0 . 9 5 1}$ & $\mathbf{0 . 8 7 2}$ & $\mathbf{0 . 6 4 3}$ & $\mathbf{0 . 3 5 6}$ \\
22. Germany & $\mathbf{0 . 9 4 4}$ & $\mathbf{0 . 9 4 9}$ & $\mathbf{0 . 8 9 5}$ & $\mathbf{0 . 7 6 4}$ & $\mathbf{0 . 4 7 7}$ \\
23. Italy & $\mathbf{0 . 9 7 7}$ & $\mathbf{0 . 9 8 5}$ & $\mathbf{0 . 8 8 8}$ & $\mathbf{0 . 6 4 4}$ & $\mathbf{0 . 4 0 3}$ \\
24. Netherlands & $\mathbf{0 . 9 4 2}$ & $\mathbf{0 . 9 5 3}$ & $\mathbf{0 . 9 1 2}$ & $\mathbf{0 . 8 1 1}$ & $\mathbf{0 . 5 5 8}$ \\
25. Portugal & $\mathbf{0 . 9 3 8}$ & $\mathbf{0 . 9 4 0}$ & $\mathbf{0 . 9 4 7}$ & $\mathbf{0 . 7 6 6}$ & $\mathbf{0 . 6 7 2}$ \\
26. Spain & $\mathbf{0 . 9 7 7}$ & $\mathbf{0 . 9 8 5}$ & $\mathbf{0 . 9 5 8}$ & $\mathbf{0 . 8 0 8}$ & $\mathbf{0 . 5 3 2}$ \\
\hline Average & 0.949 & 0.921 & 0.874 & 0.754 & 0.504 \\
\hline
\end{tabular}

Notes: This table shows the Clark-West corrected U-statistics to compare out-of-sample predictive power between the random walk model and predictive regression with optimal US factors and PPP. The Clark-West U-statistics are greater than one when the random walk model shows superior out-of-sample forecasting ability. Bold fonts indicate the rejection of equal predictive power between the random walk model and predictive regression with optimal US factors and PPP at the $10 \%$ level. 
Table 7. Out-of-Sample Analysis: Optimal Factors and PPP vs. PPP

\begin{tabular}{|l|r|r|r|r|r|}
\hline & 1 month & 3 month & 6 months & 12 months & 24 months \\
\hline 1. Australia & $\mathbf{0 . 9 6 3}$ & $\mathbf{0 . 9 7 9}$ & 0.994 & 0.986 & $\mathbf{0 . 9 4 4}$ \\
2. Canada & 0.993 & $\mathbf{0 . 9 6 9}$ & 0.998 & 0.987 & 1.019 \\
3. Chile & 1.060 & $\mathbf{0 . 9 7 5}$ & 1.036 & $\mathbf{0 . 6 6 9}$ & $\mathbf{0 . 5 1 4}$ \\
4. Colombia & $\mathbf{0 . 9 7 6}$ & $\mathbf{0 . 9 7 5}$ & $\mathbf{0 . 9 6 4}$ & $\mathbf{0 . 9 6 3}$ & $\mathbf{0 . 9 5 1}$ \\
5. Denmark & $\mathbf{0 . 9 4 8}$ & 0.991 & $\mathbf{0 . 9 7 2}$ & $\mathbf{0 . 8 4 7}$ & $\mathbf{0 . 6 6 5}$ \\
6. Iceland & $\mathbf{0 . 8 7 2}$ & $\mathbf{0 . 7 9 7}$ & $\mathbf{0 . 6 5 2}$ & $\mathbf{0 . 5 0 9}$ & $\mathbf{0 . 2 3 2}$ \\
7. Japan & $\mathbf{0 . 9 6 2}$ & $\mathbf{0 . 9 6 1}$ & $\mathbf{0 . 9 3 3}$ & $\mathbf{0 . 8 6 1}$ & $\mathbf{0 . 8 4 0}$ \\
8. Korea & 0.985 & 0.986 & 0.972 & 0.975 & $\mathbf{0 . 9 6 2}$ \\
9. New Zealand & $\mathbf{0 . 9 8 8}$ & $\mathbf{0 . 9 7 3}$ & $\mathbf{0 . 9 7 2}$ & $\mathbf{0 . 9 0 3}$ & $\mathbf{0 . 6 3 4}$ \\
10. Norway & $\mathbf{0 . 9 7 1}$ & $\mathbf{0 . 9 7 3}$ & 0.986 & 0.998 & $\mathbf{0 . 9 2 9}$ \\
11. Philippines & $\mathbf{0 . 9 8 3}$ & 0.989 & 0.992 & 0.978 & $\mathbf{0 . 8 6 1}$ \\
12. Singapore & $\mathbf{0 . 9 5 0}$ & $\mathbf{0 . 9 0 1}$ & $\mathbf{0 . 8 6 6}$ & $\mathbf{0 . 9 0 1}$ & $\mathbf{0 . 8 9 0}$ \\
13. South Africa & $\mathbf{0 . 9 7 3}$ & $\mathbf{0 . 9 8 1}$ & 1.002 & 1.013 & 0.983 \\
14. Sweden & $\mathbf{0 . 9 7 5}$ & 0.991 & 0.982 & 1.020 & 1.090 \\
15. Switzerland & $\mathbf{0 . 9 8 8}$ & $\mathbf{0 . 9 6 8}$ & $\mathbf{0 . 9 7 4}$ & 1.010 & $\mathbf{0 . 8 9 8}$ \\
16. Thailand & 0.997 & 0.992 & 0.996 & 0.997 & 0.990 \\
17. UK & $\mathbf{0 . 9 5 8}$ & $\mathbf{0 . 9 7 9}$ & $\mathbf{0 . 9 6 8}$ & $\mathbf{0 . 8 0 4}$ & $\mathbf{0 . 2 9 0}$ \\
18. Austria & $\mathbf{0 . 9 5 4}$ & $\mathbf{0 . 9 8 5}$ & $\mathbf{0 . 9 7 8}$ & $\mathbf{0 . 9 3 0}$ & $\mathbf{0 . 8 2 6}$ \\
19. Belgium & $\mathbf{0 . 9 5 6}$ & 1.004 & 0.994 & $\mathbf{0 . 8 9 1}$ & $\mathbf{0 . 9 0 5}$ \\
20. Finland & $\mathbf{0 . 9 6 6}$ & $\mathbf{0 . 9 8 5}$ & 0.997 & 1.029 & 1.007 \\
21. France & $\mathbf{0 . 9 6 1}$ & 0.994 & $\mathbf{0 . 9 7 5}$ & $\mathbf{0 . 8 6 5}$ & $\mathbf{0 . 8 3 3}$ \\
22. Germany & $\mathbf{0 . 9 5 5}$ & 0.992 & $\mathbf{0 . 9 8 3}$ & $\mathbf{0 . 9 6 7}$ & 0.973 \\
23. Italy & $\mathbf{0 . 9 8 5}$ & 1.011 & $\mathbf{0 . 9 6 0}$ & $\mathbf{0 . 8 0 7}$ & $\mathbf{0 . 6 6 5}$ \\
24. Netherlands & $\mathbf{0 . 9 5 1}$ & $\mathbf{0 . 9 8 2}$ & $\mathbf{0 . 9 8 1}$ & $\mathbf{0 . 9 7 5}$ & 0.977 \\
25. Portugal & $\mathbf{0 . 9 3 8}$ & $\mathbf{0 . 9 3 2}$ & $\mathbf{0 . 9 3 4}$ & $\mathbf{0 . 7 3 6}$ & $\mathbf{0 . 5 3 9}$ \\
26. Spain & $\mathbf{0 . 9 7 8}$ & $\mathbf{0 . 9 8 7}$ & $\mathbf{0 . 9 7 0}$ & $\mathbf{0 . 8 4 9}$ & $\mathbf{0 . 6 2 8}$ \\
\hline Average & 0.969 & 0.971 & 0.963 & 0.903 & 0.809 \\
\hline
\end{tabular}

Notes: This table shows the Clark-West corrected U-statistics to compare out-of-sample predictive power between the PPP model and predictive regression with optimal factors and PPP. The Clark-West U-statistics are greater than one when the PPP model shows superior out-of-sample forecasting ability. Bold fonts indicate the rejection of equal predictive power between the PPP model and predictive regression with optimal US factors and PPP at the $10 \%$ level. 
Table 8. Predictive Regression with Macroeconomic Factors from Korea and the US: In-sample Analysis

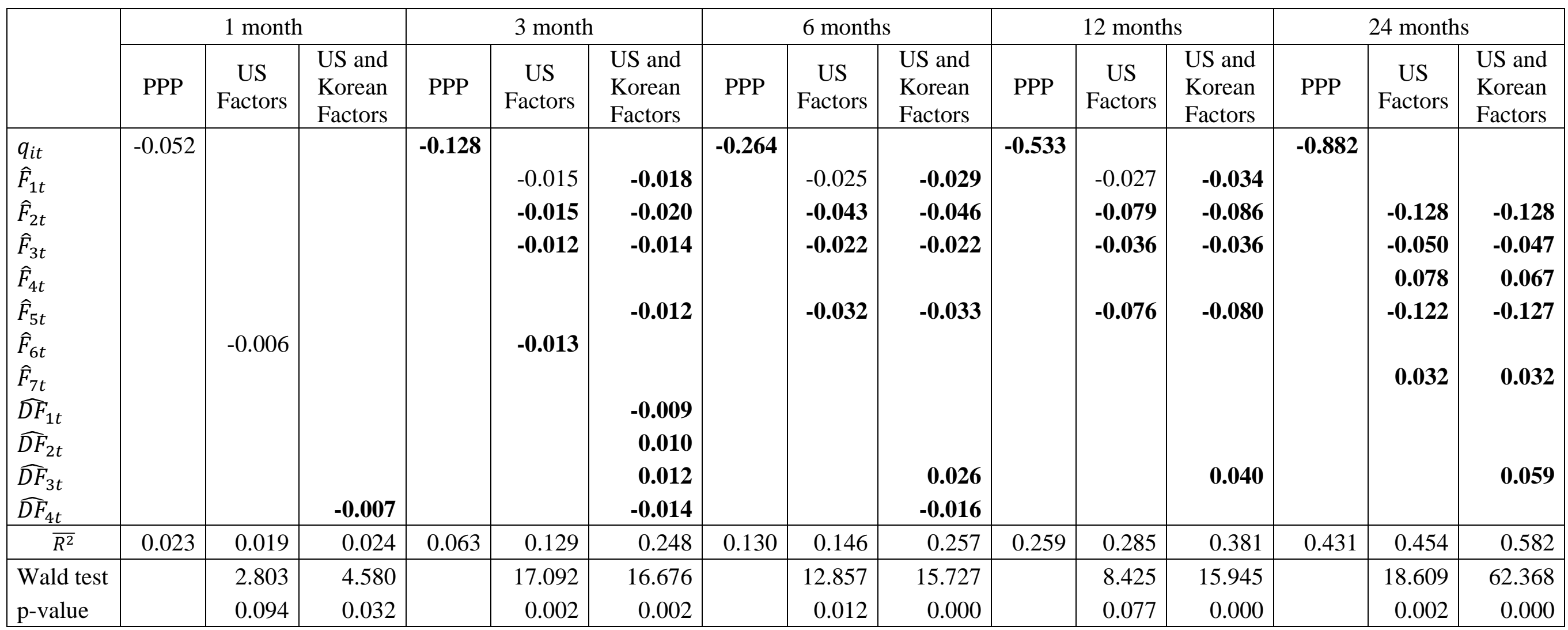

Notes: PPP shows the results of $\Delta s_{i, t+h}=\alpha_{0, i}+\alpha_{Z, i, h}^{\prime} q_{i, t}+\varepsilon_{i, t+h}$, US Factors show the results of $\Delta s_{i, t+h}=\alpha_{0, i}+\alpha_{F, h}^{\prime} \hat{f}_{t}+\varepsilon_{i, t+h}$, and US and Korean Factors show the results of $\Delta s_{i, t+h}=\alpha_{0, i}+\alpha_{F, h}^{\prime} \hat{f}_{t}+\alpha_{d F, i, h}^{\prime} \widehat{d f}_{i, t}+\varepsilon_{i, t+h}$, where $\hat{f}_{t}$ denotes estimated US macroeconomic factors and $\widehat{d f}_{i, t}$ denotes estimated Korean macroeconomic factors. The Wald test and p-value for US Factors and US and Korean Factors are the joint test results for $H_{0}: \alpha_{F, h}=0$ and $H_{0}: \alpha_{d F, i, h}=0$, respectively. Bold fonts indicate the rejection of equal predictive power at the $10 \%$ level. 
Table 9. Predictive Regression with Macroeconomic Factors from Korea and the US: Out-of-sample Analysis

\begin{tabular}{|c|c|c|c|c|c|}
\hline Horizons & 1-month & 3-month & 6-month & 12-month & 24-month \\
\hline $\begin{array}{c}\text { Clark-West U- } \\
\text { statistics }\end{array}$ & $\mathbf{0 . 8 2 4 7}$ Random walk vs. Predictive regression with macroeconomic factors from Korea and the US \\
\hline $\begin{array}{c}\text { Diebold-Mariano } \\
\text { statistics }\end{array}$ & -0.8293 & $\mathbf{0 . 5 5 2 7}$ & $\mathbf{0 . 8 5 2 1}$ & $\mathbf{0 . 8 6 5 3}$ & $\mathbf{0 . 1 7 3 7}$ \\
\hline & \multicolumn{3}{|c|}{ PPP vs. Predictive regression with macroeconomic factors from Korea and the US } \\
\hline $\begin{array}{c}\text { Clark-West U- } \\
\text { statistics }\end{array}$ & 0.0369 & 0.6074 & 0.6040 & -1.0002 \\
\hline & Random walk vs. Predictive regression with macroeconomic factors from Korea and the US and real exchange rate \\
\hline $\begin{array}{c}\text { Clark-West U- } \\
\text { statistics }\end{array}$ & $\mathbf{0 . 8 9 4 5}$ & $\mathbf{0 . 5 1 4 2}$ & $\mathbf{0 . 7 2 1 3}$ & $\mathbf{0 . 7 0 3 3}$ & $\mathbf{- 0 . 1 3 1 9}$ \\
\hline
\end{tabular}

Notes: The predictive regression with macroeconomic factors from Korea and the US is $\Delta s_{i, t+h}=\alpha_{0, i}+\alpha_{F, h}^{\prime} \hat{f}_{t}+\alpha_{d F, i, h}^{\prime} \widehat{d f}_{i, t}+\varepsilon_{i, t+h}$, and the predictive regression with macroeconomic factors from Korea and the US and real exchange rate is $\Delta s_{i, t+h}=\alpha_{0, i}+\alpha_{F, h}^{\prime} \hat{f}_{t}+$ $\alpha_{d F, i, h}^{\prime} \widehat{d f}_{i, t}+\alpha_{z, i, h} q_{i, t}+\varepsilon_{i, t+h}$. The Clark-West U-statistics are greater than one when the first model shows superior out-of-sample forecasting ability to the second one. The Diebold-Mariano test statistic is positive when the first model shows superior out-of-sample forecasting ability to the second one. Bold fonts indicate the rejection of equal predictive power at the $10 \%$ level. 
Figure 1. Estimated Factors and Related Macroeconomic Series: $\widehat{F}_{1 t}-\widehat{F}_{4 t}$
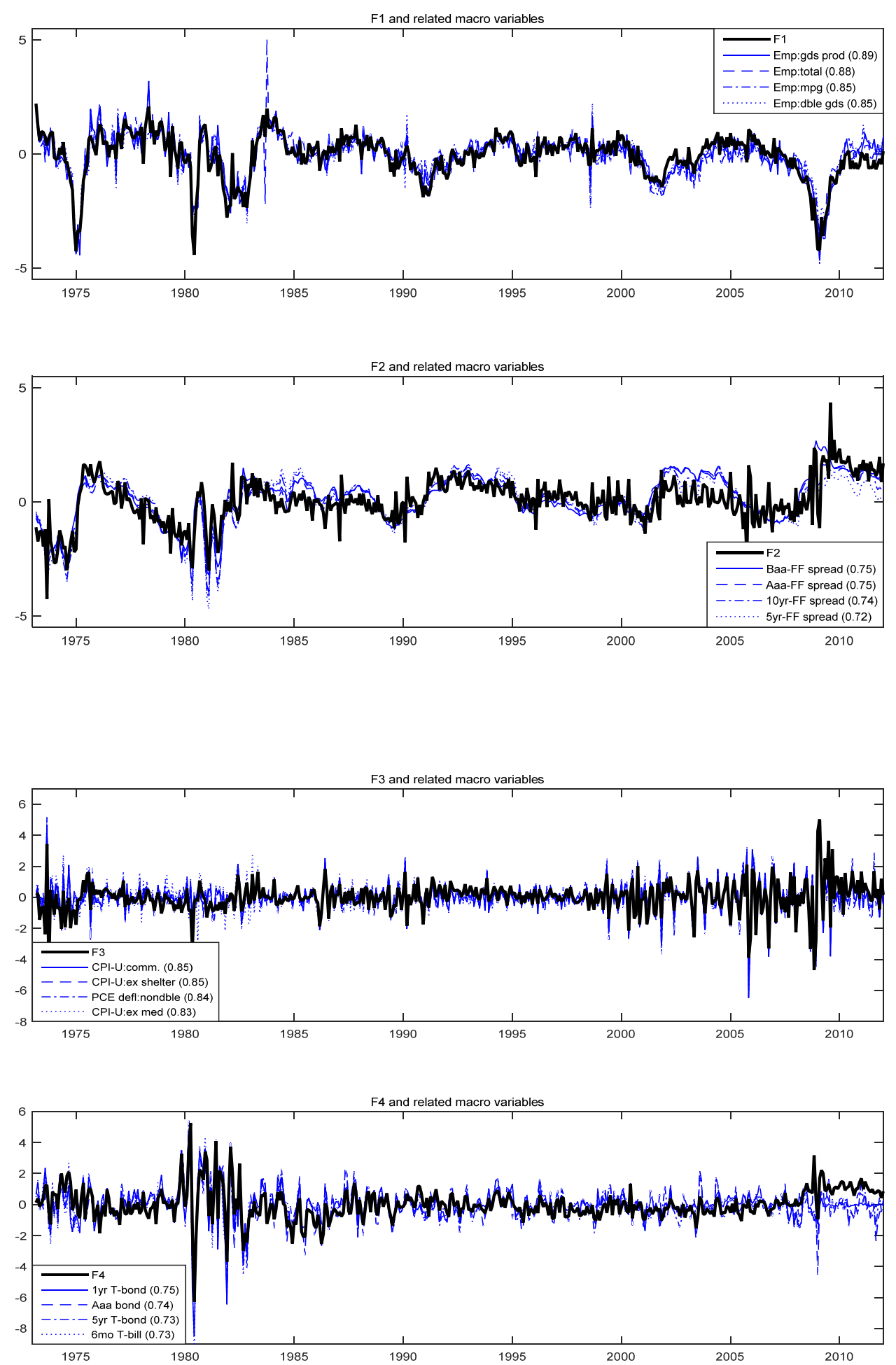

Note: Numbers in parentheses are adjusted $R^{2}$ when $\hat{F}_{i t}$ is regressed on each of macroeconomic series. 
Figure 2. Estimated Factors and Related Macroeconomic Series: $\widehat{F}_{5 t}-\widehat{F}_{6 t}$
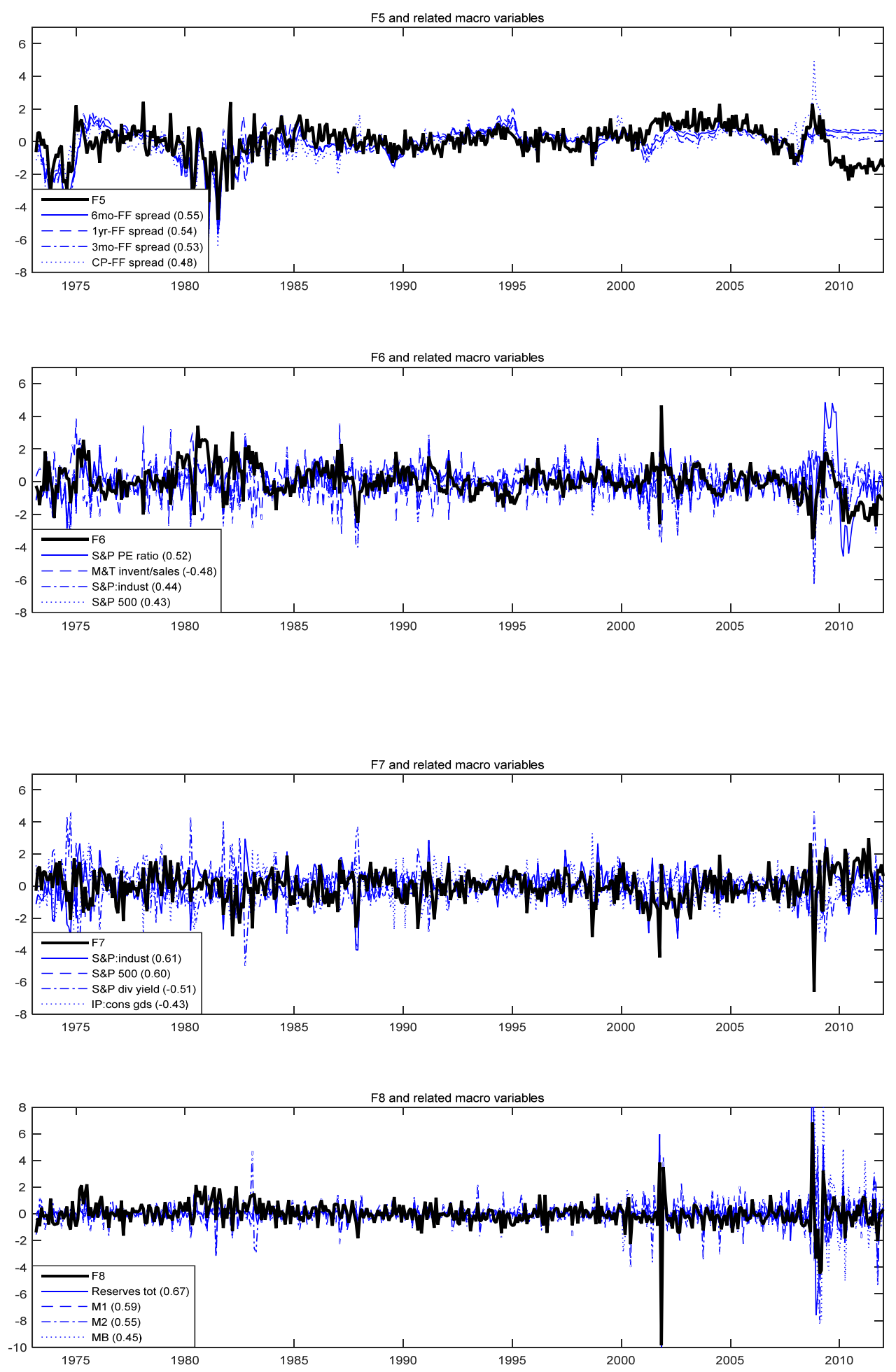

Note: Numbers in parentheses are adjusted $R^{2}$ when $\hat{F}_{i t}$ is regressed on each of macroeconomic series. 
Figure 3. Selected Frequencies of Macroeconomic Factors in Predictive Regressions with Macroeconomic Factors only
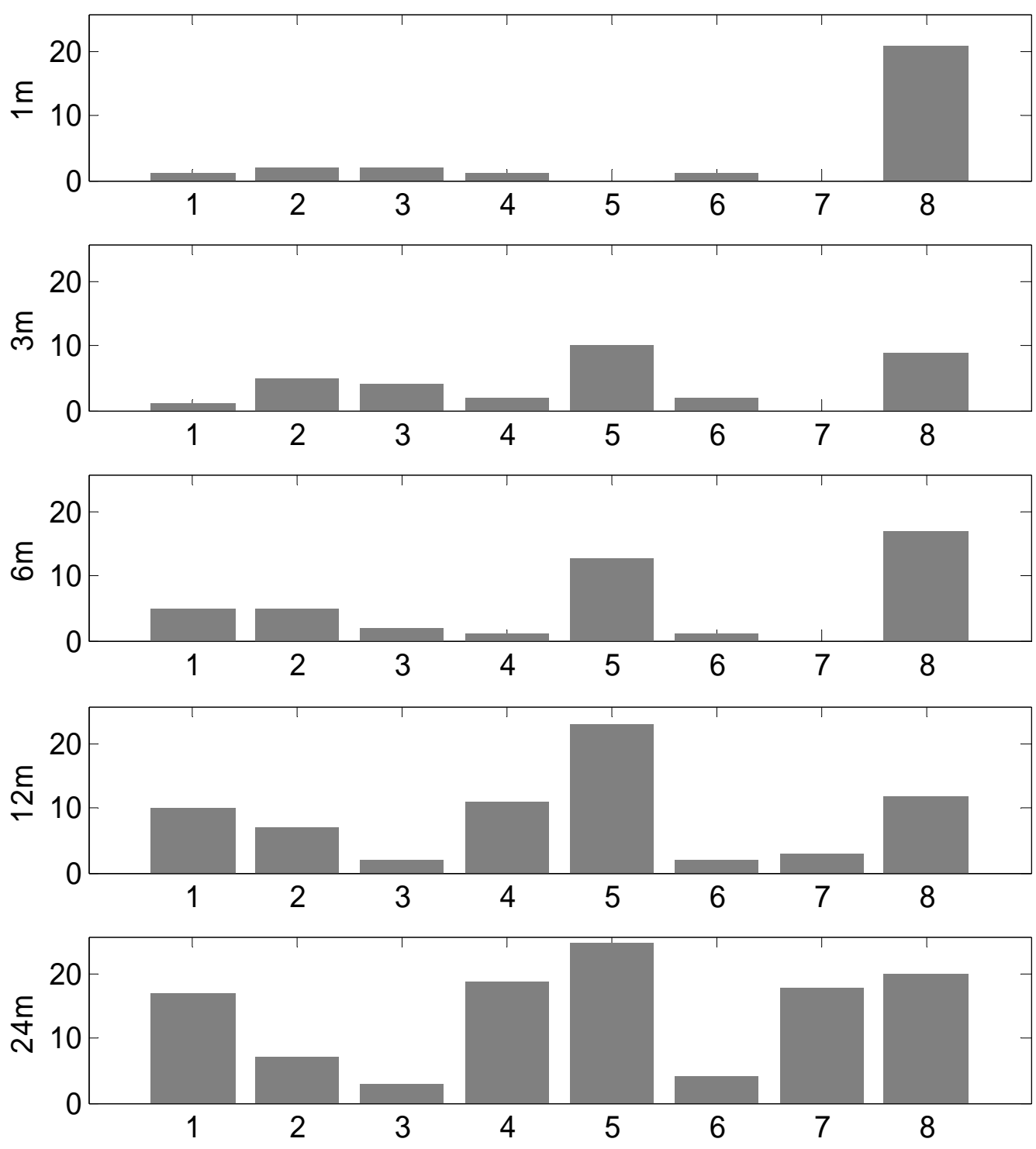

Note: This figure shows the selected frequencies of macroeconomic factors when the predictive regression has estimated macroeconomic factors only. 
Figure 4. Selected Frequencies of Macroeconomic Factors in Predictive Regressions with Macroeconomic Factors and PPP
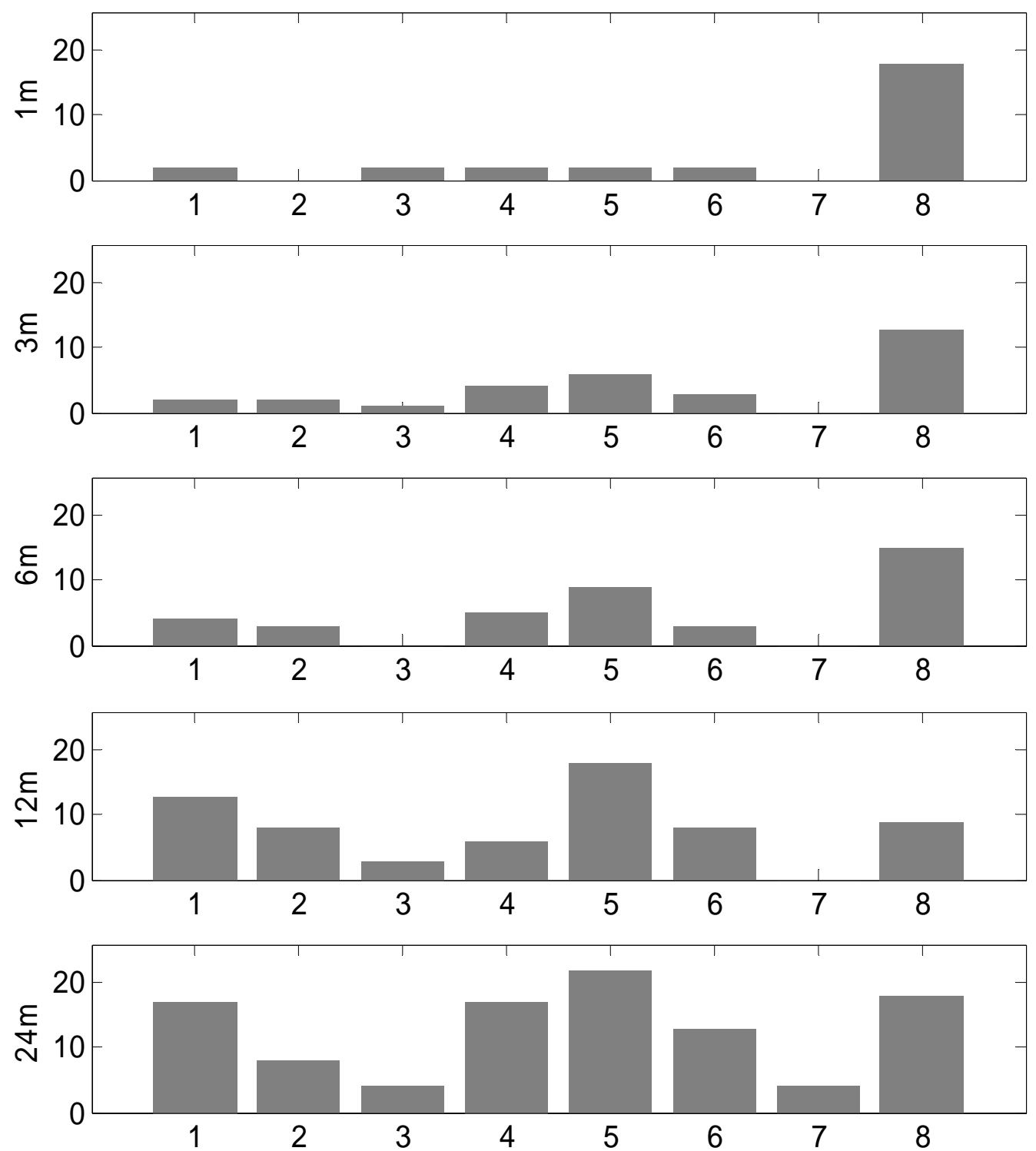

Note: This figure shows the selected frequencies of macroeconomic factors when the predictive regression has estimated macroeconomic factors and the real exchange rate. 
Figure 5. Selected Frequencies of Macroeconomic Factors in Out-of-sample Predictive Regressions with PPP
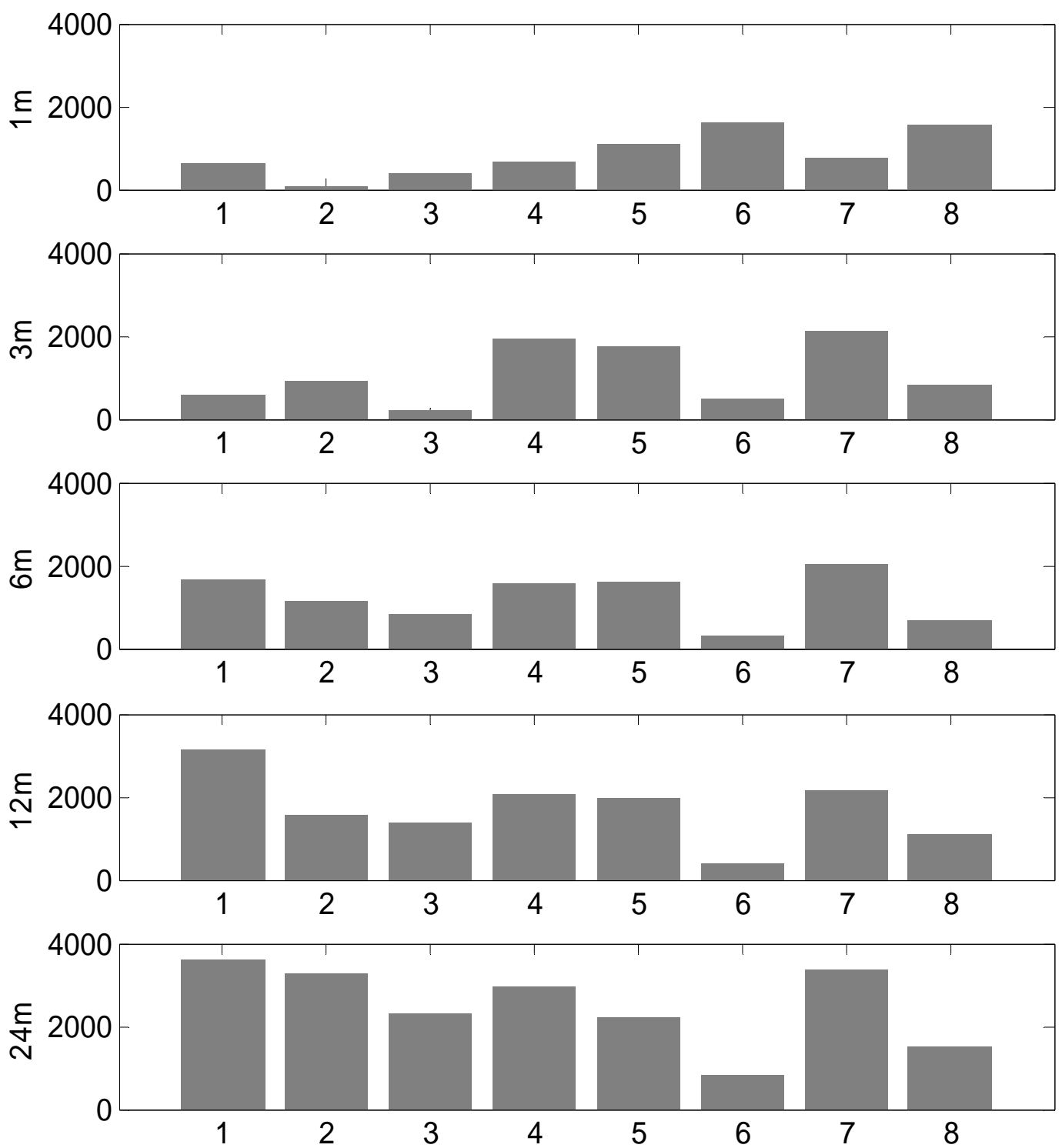

Note: This figure shows the selected frequencies of macroeconomic factors by the BIC when the predictive regression has estimated macroeconomic factors and the real exchange rate in the out-of-sample analysis. 
Appendix

Table A1. Results of Factor-augmented Predictive Regression: One-month Horizon

\begin{tabular}{|c|c|c|c|c|c|c|c|c|}
\hline \multirow{2}{*}{$\begin{array}{c}\text { One Month } \\
\text { Horizon }\end{array}$} & \multicolumn{7}{|c|}{ Bias-corrected coefficients } & \multirow{2}{*}{ adj_R ${ }^{2}$} \\
\hline & $q_{i t}$ & $\widehat{F}_{1 t}$ & $\hat{F}_{3 t}$ & $\hat{F}_{4 t}$ & $\hat{F}_{5 t}$ & $\hat{F}_{6 t}$ & $\hat{F}_{8 t}$ & \\
\hline 1. Australia & -0.0263 & & & & 0.0053 & & & 0.0164 \\
\hline 2. Canada & -0.0189 & & & & 0.0028 & & 0.0030 & 0.0312 \\
\hline 3. Chile & -0.0611 & & -0.0143 & & & & & 0.0808 \\
\hline 4. Colombia & -0.0050 & & & -0.0028 & & & & 0.0074 \\
\hline 5. Denmark & -0.0157 & & & & & & 0.0050 & 0.0169 \\
\hline 6. Iceland & -0.0302 & -0.0074 & & & & & 0.0070 & 0.0513 \\
\hline 7. Japan & -0.0136 & & & & & 0.0044 & & 0.0130 \\
\hline 8. Korea & -0.0359 & -0.0030 & & & & & & 0.0217 \\
\hline $\begin{array}{l}\text { 9. New } \\
\text { Zealand }\end{array}$ & -0.0087 & & & & & & 0.0048 & 0.0096 \\
\hline 10. Norway & -0.0220 & & & & & & 0.0048 & 0.0208 \\
\hline 11. Philippines & -0.0091 & & & & & & 0.0025 & 0.0056 \\
\hline 12. Singapore & -0.0132 & & & & & & 0.0019 & 0.0130 \\
\hline $\begin{array}{l}\text { 13. South } \\
\text { Africa }\end{array}$ & -0.0113 & & & & & & 0.0043 & 0.0086 \\
\hline 14. Sweden & -0.0142 & & & & & & 0.0041 & 0.0144 \\
\hline $\begin{array}{l}15 . \\
\text { Switzerland }\end{array}$ & -0.0264 & & & & & 0.0047 & & 0.0170 \\
\hline 16. Thailand & -0.0111 & & & -0.0012 & & & & 0.0040 \\
\hline 17. UK & -0.0278 & & -0.0026 & & & & & 0.0148 \\
\hline 18. Austria & -0.0195 & & & & & & 0.0051 & 0.0199 \\
\hline 19. Belgium & -0.0120 & & & & & & 0.0050 & 0.0146 \\
\hline 20. Finland & -0.0181 & & & & & & 0.0049 & 0.0218 \\
\hline 21. France & -0.0180 & & & & & & 0.0049 & 0.0187 \\
\hline 22. Germany & -0.0188 & & & & & & 0.0052 & 0.0197 \\
\hline 23. Italy & -0.0130 & & & & & & 0.0049 & 0.0149 \\
\hline $\begin{array}{l}24 . \\
\text { Netherlands }\end{array}$ & -0.0178 & & & & & & 0.0050 & 0.0175 \\
\hline 25. Portugal & 0.0033 & & & & & & 0.0064 & 0.0213 \\
\hline 26. Spain & -0.0078 & & & & & & 0.0042 & 0.0087 \\
\hline
\end{tabular}

Notes: This table shows the results of $\Delta s_{i, t+h}=\alpha_{0, i}+\alpha_{F, i, h}^{\prime} \hat{f}_{t}+\alpha_{Z, i, h}^{\prime} q_{i t}+\varepsilon_{i, t+h}$ where $\hat{f}_{t}$ denotes estimated US macroeconomic factors. Coefficients are bias-corrected. The results for other forecast horizons (three-month, six-month, 12-month, and 24-month horizons) are available upon request. 
Table A2. List of Korean Macroeconomic Variables

\begin{tabular}{|c|c|c|c|}
\hline Number & Sector & Variable Name & Transformation \\
\hline 1 & \multirow{11}{*}{ Market interest rates } & Uncollateralized Call Rates (Overnight) & 2 \\
\hline 2 & & $\begin{array}{l}\text { Uncollateralized Call Rates (Overnight, Direct Interbank } \\
\text { Transactions) }\end{array}$ & 2 \\
\hline 3 & & $\begin{array}{l}\text { Uncollateralized Call Rates (Overnight, Intermediated } \\
\text { Transactions) }\end{array}$ & 2 \\
\hline 4 & & Yields on CD (91-day) & 2 \\
\hline 5 & & Yields on CP (91-day) & 2 \\
\hline 6 & & Yields of National Housing Bonds Type 1 (5-year) & 2 \\
\hline 7 & & Yields of Treasury Bonds (3-year) & 2 \\
\hline 8 & & Yields of Treasury Bonds (5-year) & 2 \\
\hline 9 & & Yields of Financial Debentures (1-year) & 2 \\
\hline 10 & & Yields of Financial Debentures (3-Year) & 2 \\
\hline 11 & & Yields of Corporate Bonds : O.T.C. (3-year, AA-) & 2 \\
\hline 12 & \multirow{4}{*}{$\begin{array}{l}\text { Market interest rate } \\
\text { spreads }\end{array}$} & CP-Call spread & 1 \\
\hline 13 & & CD-Call spread & 1 \\
\hline 14 & & TB (5-year)-Call spread & 1 \\
\hline 15 & & CP (AA-)-Call spread & 1 \\
\hline 16 & \multirow{17}{*}{ Import value indexes } & All items & 4 \\
\hline 17 & & Agricultural, forestry \& marine products & 4 \\
\hline 18 & & Mining products & 4 \\
\hline 19 & & Manufacturing products & 4 \\
\hline 20 & & Food products \& beverages & 4 \\
\hline 21 & & Fiber products \& leather products & 4 \\
\hline 22 & & Wood \& paper products & 4 \\
\hline 23 & & Coal products \& petroleum products & 4 \\
\hline 24 & & Chemical products & 4 \\
\hline 25 & & Non-metallic mineral products & 4 \\
\hline 26 & & Basic metal products & 4 \\
\hline 27 & & Metal products & 4 \\
\hline 28 & & General machinery & 4 \\
\hline 29 & & Electrical \& electronic equipment & 4 \\
\hline 30 & & Precision equipment & 4 \\
\hline 31 & & Transport equipment & 4 \\
\hline 32 & & Other manufacturing products & 4 \\
\hline 33 & \multirow{2}{*}{ Export value indexes } & All items & 4 \\
\hline 34 & & Agricultural, forestry $\&$ marine products & 4 \\
\hline
\end{tabular}




\begin{tabular}{|c|c|c|c|}
\hline Number & Sector & Variable Name & Transformation \\
\hline 35 & \multirow{14}{*}{ Export value indexes } & Manufacturing products & 4 \\
\hline 36 & & Food products \& beverages & 4 \\
\hline 37 & & Fiber products \& leather products & 4 \\
\hline 38 & & Wood \& paper products & 4 \\
\hline 39 & & Coal products \& petroleum products & 4 \\
\hline 40 & & Chemical products & 4 \\
\hline 41 & & Non-metallic mineral products & 4 \\
\hline 42 & & Basic metal products & 4 \\
\hline 43 & & Metal products & 4 \\
\hline 44 & & General machinery & 4 \\
\hline 45 & & Electrical \& electronic equipment & 4 \\
\hline 46 & & Precision equipment & 4 \\
\hline 47 & & Transport equipment & 4 \\
\hline 48 & & Other manufacturing products & 4 \\
\hline 49 & \multirow{7}{*}{$\begin{array}{l}\text { Producer price } \\
\text { indexes (basic } \\
\text { groups) }\end{array}$} & All items & 5 \\
\hline 50 & & Goods & 5 \\
\hline 51 & & Agricultural, forestry \& marine products & 5 \\
\hline 52 & & Services & 5 \\
\hline 53 & & Transportation & 5 \\
\hline 54 & & Financial $\&$ insurance activities & 5 \\
\hline 55 & & Real estate activities & 5 \\
\hline 56 & \multirow{7}{*}{$\begin{array}{c}\text { Consumer price } \\
\text { indexes_(2010=100) } \\
\text { (; all cities })\end{array}$} & Total item & 5 \\
\hline 57 & & Food and non-alcoholic beverages & 5 \\
\hline 58 & & Housing, water, electricity, gas and other fuels & 5 \\
\hline 59 & & $\begin{array}{l}\text { Furnishings, household equipment and routine household } \\
\text { maintenance }\end{array}$ & 5 \\
\hline 60 & & Recreation and culture & 5 \\
\hline 61 & & Restaurants and hotels & 5 \\
\hline 62 & & Miscellaneous goods and services & 5 \\
\hline 63 & \multirow{6}{*}{$\begin{array}{l}\text { Housing purchase } \\
\text { price index }\end{array}$} & All Groups & 4 \\
\hline 64 & & All Groups (Seoul) & 4 \\
\hline 65 & & Detached Dwelling & 4 \\
\hline 66 & & Row House & 4 \\
\hline 67 & & Apartment & 4 \\
\hline 68 & & Apartment (Seoul) & 4 \\
\hline
\end{tabular}




\begin{tabular}{|c|c|c|c|}
\hline Number & Sector & Variable Name & Transformation \\
\hline 69 & \multirow{14}{*}{$\begin{array}{l}\text { Money and banking } \\
\text { (monetary } \\
\text { aggregates, deposits, } \\
\text { loans and discounts, } \\
\text { etc.) }\end{array}$} & Bank Notes and Coins in Circulation (End Of) & 5 \\
\hline 70 & & Monetary Base (End Of) & 5 \\
\hline 71 & & M1 (Narrow Money, End Of) & 5 \\
\hline 72 & & M1-MMF (End of) & 5 \\
\hline 73 & & M2 (Broad Money, End Of) & 5 \\
\hline 74 & & Lf (End Of) & 5 \\
\hline 75 & & L (End of) & 5 \\
\hline 76 & & Seasonally Adjusted M1 (End of) & 5 \\
\hline 77 & & Seasonally Adjusted M2 (End of) & 5 \\
\hline 78 & & Seasonally Adjusted Lf (End Of) & 5 \\
\hline 79 & & Total Deposits of CBs \& SBs (End Of) & 5 \\
\hline 80 & & Time \& Savings Deposits of CBs \& SBs (End Of) & 5 \\
\hline 81 & & Loans of CBs \& SBs (End Of) & 5 \\
\hline 82 & & Turnover Ratio of Demand Deposits, CBs \& SBs & 2 \\
\hline 83 & \multirow{5}{*}{$\begin{array}{l}\text { Loans \& discounts } \\
\text { by fund (CBs \& SBs, } \\
\text { End of) }\end{array}$} & Total Loans (CBs \& SBs) & 5 \\
\hline 84 & & Equipment & 5 \\
\hline 85 & & Operation & 5 \\
\hline 86 & & Loans With Banking Funds & 5 \\
\hline 87 & & Loans With Gov't Funds & 5 \\
\hline 88 & $\begin{array}{l}\text { Loans and discounts } \\
\text { of the Bank of Korea }\end{array}$ & TOTAL & 5 \\
\hline 89 & \multirow{16}{*}{$\begin{array}{c}\text { Value of machinery } \\
\text { orders received }\end{array}$} & Total Value Ordered & 4 \\
\hline 90 & & Domestic Demand & 4 \\
\hline 91 & & Government and Public & 4 \\
\hline 92 & & Private Demand & 4 \\
\hline 93 & & Manufacturing & 4 \\
\hline 94 & & Non-Manufacturing & 4 \\
\hline 95 & & Agencies & 4 \\
\hline 96 & & Overseas Demand & 4 \\
\hline 97 & & Engines & 4 \\
\hline 98 & & Special Purpose Machinery & 4 \\
\hline 99 & & Metal Cutting and Forming & 4 \\
\hline 100 & & General Purpose Machinery & 4 \\
\hline 101 & & Communication Equipment & 4 \\
\hline 102 & & Electrical Machinery & 4 \\
\hline 103 & & Motor Vehicles & 4 \\
\hline 104 & & Total Value Ordered (Excluding Vessels) & 4 \\
\hline
\end{tabular}




\begin{tabular}{|c|c|c|c|}
\hline Number & Sector & Variable Name & Transformation \\
\hline 105 & \multirow{4}{*}{$\begin{array}{c}\text { Value of machinery } \\
\text { orders received }\end{array}$} & Domestic Demand (Excluding Vessels) & 4 \\
\hline 106 & & Government and Public (Excluding Vessels) & 4 \\
\hline 107 & & Private Demand (Excluding Vessels) & 4 \\
\hline 108 & & Overseas Demand (Excluding Vessels) & 4 \\
\hline 109 & \multirow{21}{*}{$\begin{array}{l}\text { Value of domestic } \\
\text { construction orders } \\
\text { received }\end{array}$} & Total Orders Received & 4 \\
\hline 110 & & Public & 4 \\
\hline 111 & & Central Government & 4 \\
\hline 112 & & Local Government & 4 \\
\hline 113 & & Public Corporation & 4 \\
\hline 114 & & Other Public Body & 4 \\
\hline 115 & & Private & 4 \\
\hline 116 & & Manufacturing & 4 \\
\hline 117 & & Non-Manufacturing & 4 \\
\hline 118 & & Building & 4 \\
\hline 119 & & Dwellings & 4 \\
\hline 120 & & Offices and Stores & 4 \\
\hline 121 & & Factory and Storage & 4 \\
\hline 122 & & Public Offices & 4 \\
\hline 123 & & Others & 4 \\
\hline 124 & & Civil Engineering & 4 \\
\hline 125 & & Roads and Bridges & 4 \\
\hline 126 & & Water Supply and Sewerage & 4 \\
\hline 127 & & Generation of Electricity & 4 \\
\hline 128 & & Land Development & 4 \\
\hline 129 & & Installation of Machinery & 4 \\
\hline 130 & \multirow{11}{*}{$\begin{array}{l}\text { Inventory index by } \\
\text { industry }\end{array}$} & All Groups & 4 \\
\hline 131 & & Mining \& Manufacturing & 4 \\
\hline 132 & & Mining and quarrying & 4 \\
\hline 133 & & Mining of Coal, Crude Petroleum and Natural Gas & 4 \\
\hline 134 & & Mining of Non-metallic Minerals, Except Fuel & 4 \\
\hline 135 & & Manufacturing & 4 \\
\hline 136 & & Manufacture of Food Products & 4 \\
\hline 137 & & Manufacture of Beverages & 4 \\
\hline 138 & & Manufacture of Tobacco Products & 4 \\
\hline 139 & & Manufacture of Textiles, Except Apparel & 4 \\
\hline 140 & & $\begin{array}{l}\text { Manufacture of wearing apparel, Clothing Accessories and } \\
\text { Fur Articles }\end{array}$ & 4 \\
\hline
\end{tabular}




\begin{tabular}{|c|c|c|c|}
\hline Number & Sector & Variable Name & Transformation \\
\hline 141 & \multirow{17}{*}{$\begin{array}{l}\text { Inventory index by } \\
\text { industry }\end{array}$} & $\begin{array}{l}\text { Tanning and Dressing of Leather, Manufacture of Luggage } \\
\text { and Footwear }\end{array}$ & 4 \\
\hline 142 & & $\begin{array}{l}\text { Manufacture of Wood and of Products of Wood and Cork ; } \\
\text { Except Furniture }\end{array}$ & 4 \\
\hline 143 & & Manufacture of Pulp, Paper and Paper Products & 4 \\
\hline 144 & & $\begin{array}{l}\text { Manufacture of Coke, Hard-coal and Lignite Fuel Briquettes } \\
\text { and Refining }\end{array}$ & 4 \\
\hline 145 & & $\begin{array}{l}\text { Manufacture of Chemicals and Chemical Products (Except } \\
\text { Pharmaceuticals }\end{array}$ & 4 \\
\hline 146 & & Manufacture of Rubber and Plastic Products & 4 \\
\hline 147 & & Manufacture of Other Non-metallic Mineral Products & 4 \\
\hline 148 & & Manufacture of Basic Metal Products & 4 \\
\hline 149 & & $\begin{array}{l}\text { Manufacture of Fabricated Metal Products, Except Machinery } \\
\text { and Furniture }\end{array}$ & 4 \\
\hline 150 & & $\begin{array}{l}\text { Manufacture of Electronic Components, Computer, Radio, } \\
\text { Television and }\end{array}$ & 4 \\
\hline 151 & & $\begin{array}{l}\text { Manufacture of Medical, Precision and Optical Instruments, } \\
\text { Watches and }\end{array}$ & 4 \\
\hline 152 & & Manufacture of Electrical Equipment & 4 \\
\hline 153 & & Manufacture of Other Machinery and Equipment & 4 \\
\hline 154 & & Manufacture of Motor Vehicles, Trailers and Semitrailers & 4 \\
\hline 155 & & Manufacture of Other Transport Equipment & 4 \\
\hline 156 & & Manufacture of Furniture & 4 \\
\hline 157 & & Other Manufacturing & 4 \\
\hline 158 & \multirow{14}{*}{$\begin{array}{l}\text { Manufacturing } \\
\text { production index by } \\
\text { special classification }\end{array}$} & All Items & 4 \\
\hline 159 & & Capital Goods & 4 \\
\hline 160 & & Manufacturing Equipment & 4 \\
\hline 161 & & Electricity & 4 \\
\hline 162 & & Communication & 4 \\
\hline 163 & & Transportation Equipment & 4 \\
\hline 164 & & Agriculture & 4 \\
\hline 165 & & Construction & 4 \\
\hline 166 & & Office & 4 \\
\hline 167 & & Others & 4 \\
\hline 168 & & Intermediate Goods & 4 \\
\hline 169 & & Manufacturing & 4 \\
\hline 170 & & Construction & 4 \\
\hline 171 & & Fuel and Electricity & 4 \\
\hline
\end{tabular}




\begin{tabular}{|c|c|c|c|}
\hline Number & Sector & Variable Name & Transformation \\
\hline 172 & \multirow{4}{*}{$\begin{array}{l}\text { Manufacturing } \\
\text { production index by } \\
\text { special classification }\end{array}$} & Others & 4 \\
\hline 173 & & Consumer Goods & 4 \\
\hline 174 & & Durable Consumer Goods & 4 \\
\hline 175 & & Non-Durable Consumer Goods & 4 \\
\hline 176 & \multirow{22}{*}{$\begin{array}{c}\text { Manufacturing } \\
\text { operation ratio index }\end{array}$} & Manufacture & 2 \\
\hline 177 & & Food Products & 2 \\
\hline 178 & & Beverages Products & 2 \\
\hline 179 & & Tobacco Products & 2 \\
\hline 180 & & Petroleum Products & 2 \\
\hline 181 & & Manufacture of Apparel, Accessories, and Fur Articles & 2 \\
\hline 182 & & Tanning and Dressing of Leather, Luggage, and Footwear & 2 \\
\hline 183 & & Manufacture of Wood and of Wood and Cork Products & 2 \\
\hline 184 & & Pulp, Paper ${ }_{2}$ and Paper Products & 2 \\
\hline 185 & & $\begin{array}{l}\text { Coke, hard-coal and Lignite Fuel Briquettes and Refined } \\
\text { Petroleum Products }\end{array}$ & 2 \\
\hline 186 & & Chemicals and Chemical Products & 2 \\
\hline 187 & & Rubber and Plastic Products & 2 \\
\hline 188 & & Non-metallic Mineral Products & 2 \\
\hline 189 & & Basic Metal Products & 2 \\
\hline 190 & & Fabricated Metal Products & 2 \\
\hline 191 & & $\begin{array}{l}\text { Electronic Components, Computer, Radio, Television and } \\
\text { Communication Equipment and Apparatuses }\end{array}$ & 2 \\
\hline 192 & & Medical, Precision and Optical Instruments, Watches & 2 \\
\hline 193 & & Electrical Equipment & 2 \\
\hline 194 & & Other Machinery and Equipment & 2 \\
\hline 195 & & Motor Vehicles, Trailers and Semitrailers & 2 \\
\hline 196 & & Other Transport Equipment & 2 \\
\hline 197 & & Other Manufacturing & 2 \\
\hline 198 & \multirow{4}{*}{$\begin{array}{l}\text { Index of mining and } \\
\text { manufacturing } \\
\text { industrial products }\end{array}$} & All Groups & 4 \\
\hline 199 & & Mining \& Manufacturing & 4 \\
\hline 200 & & Mining & 4 \\
\hline 201 & & Manufacturing & 4 \\
\hline 202 & \multirow{5}{*}{$\begin{array}{l}\text { Shipment index by } \\
\text { industry }\end{array}$} & All Groups & 4 \\
\hline 203 & & Mining and Manufacturing & 4 \\
\hline 204 & & Mining & 4 \\
\hline 205 & & Manufacturing & 4 \\
\hline 206 & & Electricity, gas & 4 \\
\hline
\end{tabular}




\begin{tabular}{|c|c|c|c|}
\hline Number & Sector & Variable Name & Transformation \\
\hline 207 & $\begin{array}{c}\text { estimation index of } \\
\text { equipment } \\
\text { investment }\end{array}$ & Total Equipment Index (S.A.) & 4 \\
\hline 208 & \multirow{5}{*}{$\begin{array}{l}\text { Composite index of } \\
\text { business indicators }\end{array}$} & Leading Composite Index & 4 \\
\hline 209 & & Coincident Composite Index & 4 \\
\hline 210 & & Lagging Composite Index & 4 \\
\hline 211 & & Cycle of Coincident Composite Index & 4 \\
\hline 212 & & Cycle of Leading Composite Index & 4 \\
\hline 213 & \multirow{3}{*}{$\begin{array}{c}\text { Transactions in } \\
\text { securities and stock } \\
\text { price index }\end{array}$} & KOSPI (End Of) & 4 \\
\hline 214 & & Weighted Average of Dividend Yield & 2 \\
\hline 215 & & Price Earnings Ratio & 4 \\
\hline
\end{tabular}

Note: Transformation procedures for each macro variable are as follows.

\begin{tabular}{|c|c|}
\hline $\begin{array}{c}\text { Transformation } \\
\#\end{array}$ & Transformation \\
\hline 1 & $\Delta l v$ \\
\hline 2 & $l n$ \\
\hline 3 & $\Delta l n$ \\
\hline 4 & $\Delta^{2} l n$ \\
\hline 5 & \\
\hline
\end{tabular}

